\title{
Natural products from the integument of nonavian reptiles
}

\author{
Paul J. Weldon, ${ }^{* a}$ Birte Flachsbarth ${ }^{b}$ and Stefan Schulz ${ }^{* b}$ \\ Received 25th February 2008 \\ First published as an Advance Article on the web 11th April 2008 \\ DOI: $10.1039 / b 509854 h$
}

Covering: 1934 to 2007

This review describes the epidermal and glandular chemistry of nonavian reptiles in relation to proposed functions, and includes more than 170 references. The results are presented according to the different reptile taxa.

\author{
1 Introduction \\ 2 Epidermis: Squamata \\ 3 Integumentary glands: Squamata \\ 3.1 Amphisbaenians \\ 3.1.1 Precloacal gland \\ 3.2 Lizards \\ 3.2.1 Femoral, precloacal, and preanal glands \\ 3.2.2 Urodeal gland \\ 3.2.3 Caudal gland \\ 3.3 Snakes \\ 3.3.1 Scent gland \\ 3.3.2 Nuchal gland \\ 3.3.3 Nasal gland \\ 4 Cloacal gland: Rhynchocephalia \\ 5 Testudines \\ 5.1 Rathke's gland \\ 5.2 Mental gland \\ 6 Crocodylia \\ 6.1 Gular gland \\ 6.2 Paracloacal gland \\ 7 Discussion \\ 7.1 From TLC to structural identifications \\ 7.2 Chemical diversity revealed \\ 7.3 Biosynthesis by associated microorganisms? \\ 8 Prospectus \\ 9 Acknowledgements \\ 10 References
}

"Two key words characterize the uniqueness of skin lipids: complexity and perversity." $\quad \mathrm{N}$. Nicolaides ${ }^{1}$

\section{Introduction}

The appearance of the amniote egg during the Carboniferous period 350 million years ago (mya) marked the emergence of the first fully terrestrial vertebrates and led to the evolution of reptiles. Reptilian diversity expanded dramatically during the

${ }^{a}$ Conservation and Research Center, Smithsonian Institution, 1500 Remount Road, Front Royal, 22630,VA, USA. E-mail: weldonp@si.edu ${ }^{b}$ Institute of Organic Chemistry, Technische Universität Braunschweig, Hagenring 30, 38106 Braunschweig, Germany. E-mail: stefan.schula@ tu-bs.de
Mesozoic era (245-65 mya), the so-called "Age of Reptiles", with radiations of flying, marine, semiaquatic, and various terrestrial forms, including dinosaurs. Five reptile orders from the Mesozoic have survived: Squamata (amphisbaenians, lizards, and snakes), Rhynchocephalia (tuatara), Testudines (turtles), Crocodylia (alligators and caimans, crocodiles, and gavials), and Aves (birds) (Fig. 1). Together, these taxa comprise the most speciose assemblage of extant tetrapods, with $>16000$ species occupying diverse habitats worldwide.

The evolutionary success of reptiles is due, in part, to their possession of an integument that restricts the loss of water to the environment. Cutaneous water conservation is achieved by a multilayered stratum corneum, the outermost region of dead epidermis, that is imbued with lipids. ${ }^{1-4}$ These lipids establish the transepidermal permeability barrier, impeding desiccation and the percutaneous inward passage of substances from the environment. Chemicals from the integument - the epidermis and skin glands - also protect reptiles against pathogenic microorganisms, ${ }^{5}$ ectoparasites, including disease vectors, ${ }^{6}$ and predators, ${ }^{7}$ in addition to attracting mates and eliciting other pheromonal responses. $^{8}$

Here, we describe chemicals from the integument of nonavian reptiles, their specific sources, and possible significance as skin products. Although we do not treat birds in detail, we refer broadly to what is known of the skin chemistry of tetrapods in examining primarily lipids and other low molecular weight compounds from squamates, tuatara, turtles, and crocodylians. The results of both preliminary analyses, as by thin-layer

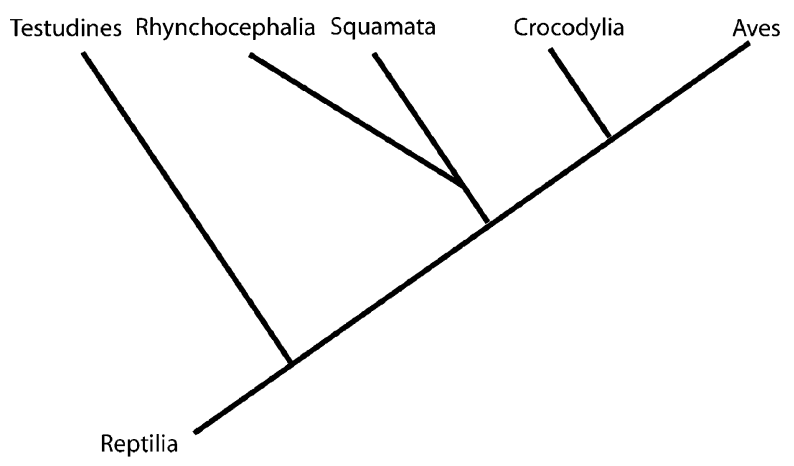

Fig. 1 A cladogram of major taxa of extant reptiles. 
chromatography (TLC), and detailed structural identifications by modern analytical methods (GC, HPLC, MS, and NMR) are summarized. We also describe what is known of proteins from the integumental glands of reptiles in order to draw attention to these poorly understood skin products.

The following section of this paper describes compounds from the epidermis of squamates, the sole group of reptiles for which the chemistry of this outermost skin layer has been detailed. Subsequent sections describe chemicals from the skin glands of each extant reptile order ${ }^{9-11}$ where secretions have been investigated beyond basic histochemistry. We refer to compounds for which characterizations are reliably described, omitting those with invalid names or very unlikely natural occurrence. In the final section, we discuss the diversity and possible adaptive trends exhibited by natural products from the integument.

\section{Epidermis: Squamata}

TLC and other general analyses of lipids from intact or shed skins of lizards and/or snakes suggest the presence of hydrocarbons,${ }^{12,13}$ free fatty acids (FFAs), ${ }^{12-19}$ alcohols, ${ }^{12-17}$ aldehydes, ${ }^{12,14}$ methyl ketones, ${ }^{12,17}$ di- and triacylglycerols, ${ }^{13-19}$ wax esters, ${ }^{12,18,20}$ sterols and their esters, ${ }^{12-19}$ phospholipids including sphingomyelin, ${ }^{12-18}$ and glycolipids. ${ }^{16,21}$ Taxonomic, ${ }^{13,14,16-18}$ sexual, ${ }^{22}$ seasonal, ${ }^{18,22}$ individual, ${ }^{18}$ and mutational $^{14}$ variation in epidermal lipids have been described.
Squalene (1) has been observed in the skins of snakes and lizards. ${ }^{23-25}$ This compound occurs in male red-sided garter snakes (Thamnophis sirtalis parietalis) from Canada, but is present in reduced amounts or absent in females and femalemimicking males ("she-males"). ${ }^{23,26}$ Mason et al. observed that courtship behaviors experimentally elicited in male garter snakes by hexane skin extracts of females were inhibited by $1 .{ }^{23}$ These investigators posited that $\mathbf{1}$, along with other unidentified components, contributes to the chemosensory recognition of male garter snakes by conspecifics.

Hydrocarbons reported from the skin of the Burmese python (Python molurus bivittatus) include a series of unbranched $\mathrm{C}_{14}-\mathrm{C}_{31}$ alkanes and mono-, di-, trimethyl- and phenylalkanes as well as alkenes (all uncharacterized). ${ }^{23}$ Alkanes with up to 35 carbons occur in the eastern indigo snake (Drymarchon corais) ${ }^{\mathbf{1 2}}$ and the leopard gecko (Eublepharis macularius). ${ }^{25}$ The indigo snake compounds, however, exhibited GC elution patterns deemed typical of petroleum hydrocarbon contaminants. ${ }^{12}$ Disagreement exists on whether hydrocarbons naturally occur on the skin surface of terrestrial vertebrates. ${ }^{13,14,25,27}$ Their presence on the epidermis may vary among species.

Cholesterol (6), which is ubiquitous in the tissues of tetrapods, is abundant on the epidermis of squamates. ${ }^{12,22,24,25,28,29}$ In the eastern indigo snake, 6 comprises $15 \%$ by weight of shed skin extracts. ${ }^{12}$ Ball ${ }^{29}$ observed proportionally more 6 in the skins of hatchling cornsnakes (Pantherophis guttata) than in those of

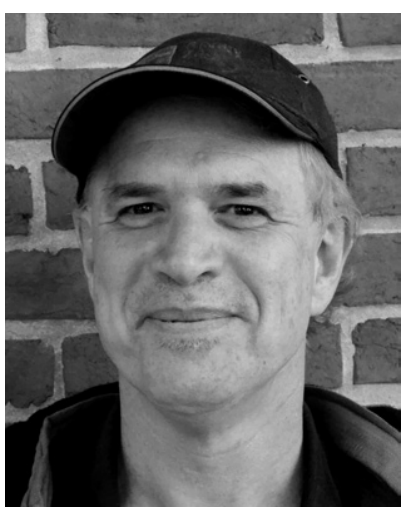

Paul J. Weldon

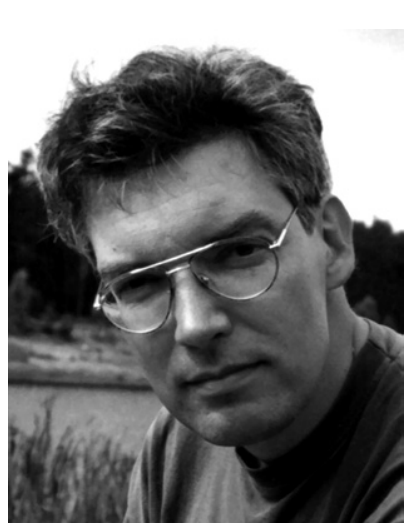

Stefan Schulz
Dr Paul J. Weldon studied Biology at the Western Connecticut State University. He obtained his PhD in zoology at the University of Tennessee and was an associate professor in the Department of Biology at Texas A\&M University, where he undertook studies on reptiles. After a stay at the National Zoological Park, Washington, D.C., he currently works at the Smithsonian Conservation and Research Center, Front Royal, $V A$.

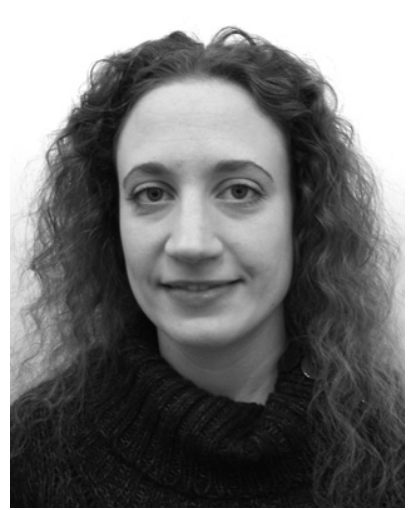

Birte Flachsbarth
Dipl.-Chem. Birte Flachsbarth studied chemistry at the Technische Universität Braunschweig and obtained her diploma in chemistry in 2004. Currently she is studying for a PhD in Organic Chemistry in the research group of Prof. Dr Stefan Schulz at the TU Braunschweig. She is working on the synthesis and identification of compounds from the cloacal gland secretion of tuatara.
Prof. Dr Stefan Schulz studied chemistry at the Universität Hamburg (PhD 1987). A postdoctoral position with Prof. J. Meinwald at Cornell University followed. After returning to Hamburg, he habilitated in 1994. In 1997 he was appointed full professor of Organic Chemistry at the Technische Universität Braunschweig. His main research area is the chemistry of extracellular signal compounds. 
adults, a contrast that may pertain to the different water permeabilities of the epidermis at these developmental stages. Other steroids found in the epidermis of squamates are coprostane (2), cholestanol (3), cholesta-3,5-diene (13), 3-methoxycholest-5-ene (19), campesterol (33), ergostanol (34), ergostenol (36), stigmastanol (42), $\beta$-sitosterol (43), stigmasterol (46), and fucosterol (48). ${ }^{24,25,28}$ Some of these sterols, such as 33 and 43, are typical microbial or plant products. Their occurrence in snakes, which are strictly predatory, is noteworthy. ${ }^{24,28}$ Compound 2, which was reported from the skin of the cornsnake, ${ }^{28}$ is a component of bile.

FFAs and fatty acids bound in triacylglycerols, wax esters, steryl esters, and other compounds are widespread on the skin of tetrapods. ${ }^{14,24,28}$ The FFAs reported from squamates contain chains with up to twenty-eight carbons, the most abundant of which are common $\mathrm{C}_{16}$ and $\mathrm{C}_{18}$ compounds. ${ }^{12,14,22,24,28-30}$ Methylbranched and hydroxylated FFAs also occur. ${ }^{28}$ Interspecific differences likely exist among snakes in FFAs of the epidermis. ${ }^{14}$ However, the different methods of extraction, storage, and analysis used in different studies, the small sample sizes typically involved, and the general failure to control for sex, ${ }^{28}$ age class, ${ }^{29}$ and other variables that could influence skin lipid composition preclude rigorous interspecific comparisons. The Japanese snakes, the habu (Protobothrops flavoviridis, Viperidae) and two ratsnakes (Elaphe climacophora and E. quadravirgata, Colubridae), exhibit familial differences in the composition of epidermal FFAs. ${ }^{30}$

Esterified saturated and monounsaturated $\mathrm{C}_{14}$ and $\mathrm{C}_{16}$ acids were observed among the triacylglycerols and mono- and diester waxes from the skin of the Burmese python. ${ }^{24}$ The monoester waxes of this snake contain saturated $\mathrm{C}_{16}-\mathrm{C}_{26}$ and $\mathrm{C}_{28}$ primary alcohols and $\mathrm{C}_{21}, \mathrm{C}_{23}, \mathrm{C}_{27}, \mathrm{C}_{29}$, and $\mathrm{C}_{31}$ secondary alcohols. $\mathrm{C}_{14}-\mathrm{C}_{24}$ acids occur among the triacylglycerols, steryl esters, and polar lipids of the black ratsnake (Pantherophis obsoleta). ${ }^{\mathbf{1 4}}$ Common $\mathrm{C}_{16}$ and $\mathrm{C}_{18}$ acids are prominent esterified components among squamates, but the abundances of different acids may vary among compound classes. ${ }^{14,24}$ Studies of these compounds may shed light on their relative contribution (via hydrolysis) to the pool of FFAs on the skin surface.

Methyl ketones are reported from the epidermis of some colubrid snakes ${ }^{12,23,28,31-35}$ and the leopard gecko. ${ }^{25}$ On the basis of their investigation of the eastern indigo snake, Ahern and Downing ${ }^{12}$ postulated that methyl ketones arise from FFAs that have undergone $\beta$-oxidation followed by decarboxylation. Female red-sided garter snakes possess a series of saturated (52-59) and Z-monounsaturated methyl ketones (60-65) with mostly odd-numbered carbon chains ranging from $\mathrm{C}_{29}$ to $\mathrm{C}_{37 .}{ }^{23,31-35}$ Bioassays revealed that males attend to these compounds to recognize $e^{23,31}$ and trail prospective mates. ${ }^{32}$ The unsaturated methyl ketones, which are more attractive to males, possess a double bond at the $\omega-9$ position. Unsaturation at this site denotes compounds potentially derived from $(Z)$-octadecenoic (oleic) acid. ${ }^{23}$ Methyl ketones $(\mathbf{5 2}, \mathbf{5 3}, \mathbf{5 5}, \mathbf{5 7 - 6 5}$ ) also occur in male and she-male garter snakes. ${ }^{26}$

Subtle variation in the composition of methyl ketones on the skin surface of female garter snakes permits males to distinguish between large and small, less preferred mates. ${ }^{33}$ Large females primarily possess monounsaturated methyl ketones, whereas small females primarily possess saturated analogs. Males also rely on methyl ketone profiles to discriminate between females from their own versus foreign dens, preferring the former as mates. ${ }^{34}$ Females from different dens possess different proportions of monounsaturated methyl ketones, whereas the amounts of saturated analogs they possess are more uniform.

Nuclear magnetic resonance $\left({ }^{13} \mathrm{C}\right)$ spectra of skin extracts of females of the eastern indigo snake, the common kingsnake (Lampropeltis getula), ${ }^{17}$ and the tropical ratsnake (Spilotes pullatus) ${ }^{36}$ exhibited signals denoting methyl ketones. The eastern indigo snake possesses saturated $\mathrm{C}_{21}-\mathrm{C}_{35}$ methyl ketones and $\mathrm{C}_{25}-\mathrm{C}_{35}$ analogs unsaturated at the $\omega-7$ position that probably are derived from $(Z)-9$-hexadecenoic (palmitoleic) acid. ${ }^{12}$ One isomeric pair each of $\mathrm{C}_{35}, \mathrm{C}_{36}$, and $\mathrm{C}_{37}$ ketodienes (66-71) showing $(6 Z, \omega-9)$ or $(8 Z, \omega-9)$ arrangements of double bonds were identified from females of the brown treesnake (Boiga irregularis), a rear-fanged constrictor accidentally introduced into Guam, where it has exterminated some native birds and threatens other wildlife. ${ }^{35}$ These ketodienes and the other methyl ketones present in this species (52-59, 61-65), if active as pheromones, might be used to control this invasive snake. ${ }^{37}$ Female leopard geckos possess saturated methyl ketones $\mathbf{5 5}$ and $\mathbf{5 7}$ as well as uncharacterized unsaturated analogs, but males do not. ${ }^{25}$

Monounsaturated $\mathrm{C}_{23}-\mathrm{C}_{33}$ primary alcohols and $\mathrm{C}_{25}-\mathrm{C}_{35}$ secondary alcohols occur in the eastern indigo snake. ${ }^{12}$ The secondary alcohols exhibit carbon-chain lengths corresponding to those of the methyl ketones present, thus pointing to a close biosynthetic relationship between these compound classes. Ahern and Downing ${ }^{12}$ postulated that the methyl ketones in this snake undergo oxidation to form acetates that give rise to primary alcohols, and that secondary alcohols arise by the reduction of methyl ketones.

Roberts $^{14}$ also observed alcohols in the black ratsnake, but failed to observe ketones in this or the other squamates she examined by TLC. Ball ${ }^{28,29}$ observed $\mathrm{C}_{12}-\mathrm{C}_{25}$ alcohols in the cornsnake, but methyl ketones were not detected. Higher concentrations of octadecanol were found in the skins of adult cornsnakes than in hatchlings, a contrast that Ball ${ }^{29}$ attributed to age-class differences in diet or lipid metabolism. Tetradecanal was also found in the cornsnake. ${ }^{28}$

Glycolipids are essential to maintaining the transepidermal water barrier of amniotes. ${ }^{16,21,38}$ These compounds are believed to act as molecular rivets, stabilizing the intercellular lipoidal lamellae of the stratum corneum and obstructing the passage of water. In mammals, acylglucosylceramides are critical to the integrity of the transepidermal water barrier, ${ }^{38}$ whereas in reptiles, including birds, sterol glycosides serve this role. ${ }^{39}$

Two classes of sterol glycosides were isolated from the skin of the bullsnake (Pituophis catenifer sayi), a sterol- $\beta$-glucoside and acylglucosylsterols with analogs acylated at C-6 of glucose. ${ }^{39}$ The acyl parts of the latter compounds consist of fatty acids with different chain lengths, primarily common $\mathrm{C}_{16}$ and $\mathrm{C}_{18}$ acids. These sterol glycosides are similar to those identified from the epidermis of the chicken (Gallus domesticus). ${ }^{40}$ Cholesterol (6) is the sole sterol in the snake-derived glycosides, whereas the chicken-derived compounds contain either cholesterol or cholestanol; the latter is a primary sterol of the avian epidermis. ${ }^{\mathbf{4 1 , 4 2}}$ The prevalence of cholestanol on the integument of birds, often overshadowing cholesterol as the chief skin sterol of tetrapods, has been related to waterproofing the plumage, ${ }^{41}$ although it is unclear if cholestanol is better suited for this function. 


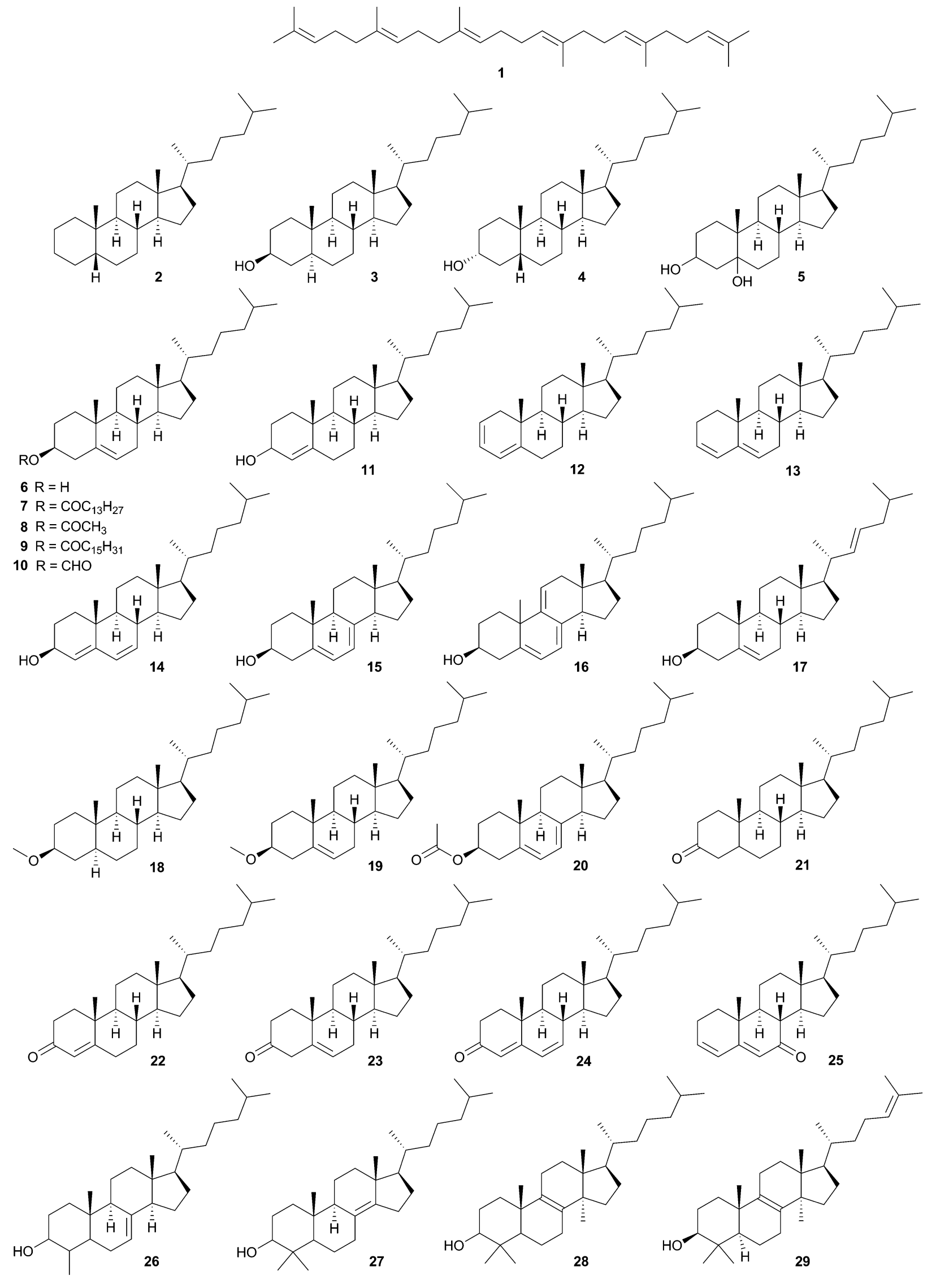


<smiles>CC(C)CCCC(C)CCC1C([C@@H](C)CCCC(C)C)CCC2C3=CCC4C(C)(C)C(O)CCC4(C)[C@H]3CCC21C</smiles>

30

33

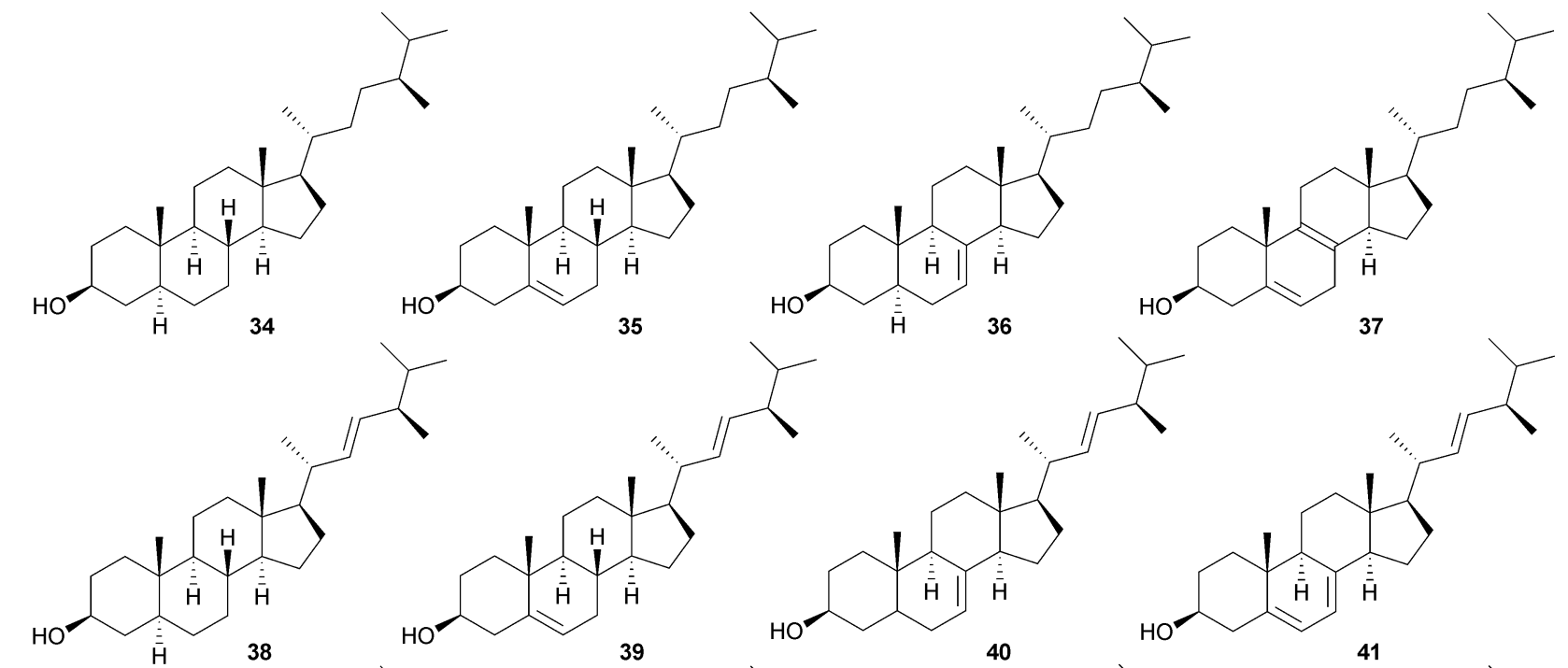

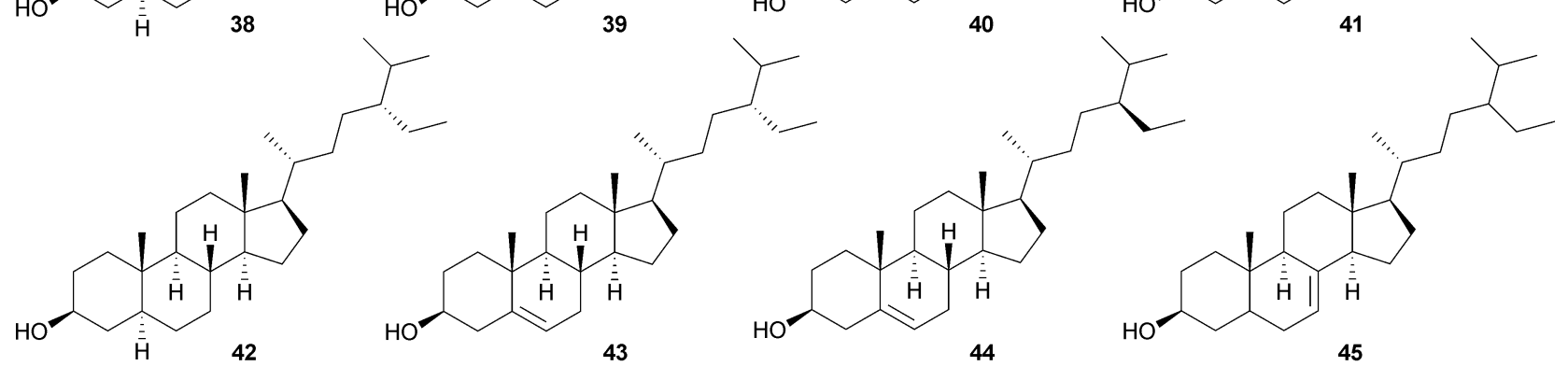<smiles>CCCC(C)C(C)C=C[C@@H](C)C1CCC2C3CC=C4CC(O)CC[C@]4(C)C3CCC21C</smiles>

43

44

45

46

HO

$\mathrm{HO}$<smiles>CCC=C(C)C</smiles><smiles>CC(=O)C1CCC2C3CCC4CC(O)CCC4(C)C3C(O)CC12C</smiles><smiles>C=C(C)C1CCC2[C@H]3CCC4CC(O)CCC4(C)C3C(O)CC12C</smiles>

\section{Integumentary glands: Squamata}

\subsection{Amphisbaenians}

3.1.1 Precloacal gland. Amphisbaenians are elongate, burrowing reptiles whose limbs are absent or reduced. They inhabit loose or sandy soils in tropical and warm temperate regions around the world. Most amphisbaenians possess precloacal glands, narrow tubes embedded in the dermis that open through a semicircular series of pores anterior to the vent. ${ }^{9,10,43}$ Secretions from these glands, which are deposited by 

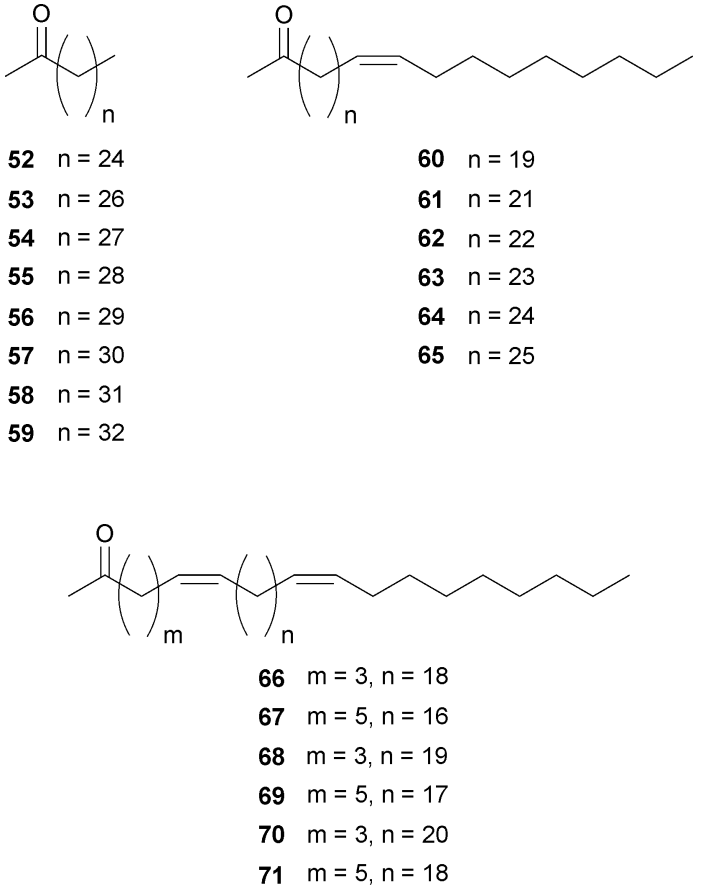

abrasion as animals crawl through their tunnels, contain pheromones involved in sexual ${ }^{44}$ and/or individual recognition. ${ }^{45}$

An analysis of the precloacal gland secretions of Blanus cinereus from Spain revealed that cholesterol (6) and cholesteryl methyl ether (19) are the main lipid components. ${ }^{46}$ Other steroids found include 13, cholesta-4,6-dien-3-ol (14), cholesta-5,7dien-3-ol (15), cholesta-5,7,9(11)-trien-3-ol (16), 3-methoxy cholestane (18), cholesta-5-en-3-one (23), 33, and $\gamma$-sitosterol (44), as well as cholest-5-en-3-yl tetradecanoate (7) and cholesta5,7-dien-3-yl acetate (20). FFAs in the secretions range in chain length from $\mathrm{C}_{9}$ to $\mathrm{C}_{18}$, the most abundant of which are dodecanoic and hexadecanoic acids. $\mathrm{A}_{18}$ methyl ester and $\mathrm{C}_{16}$ and $\mathrm{C}_{18}$ hexanoates and octanoates also were observed. Squalene (1) occurs chiefly in the secretions of males. $\boldsymbol{\alpha}$-Tocopherol (72, vitamin E), which typically is produced by microorganisms and plants, and thus may be dietary in origin, was detected only in females. This compound is a radical scavenger and may protect other compounds in the secretions from oxidation. Sexual differences also were observed in the occurrence of some FFAs and steroids.

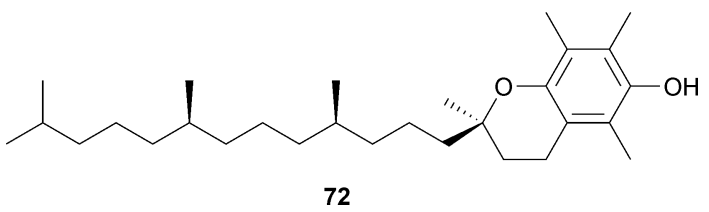

\subsection{Lizards}

3.2.1 Femoral, precloacal, and preanal glands. Lizards, overall, possess an array of glands, variously referred to as femoral, precloacal or preanal glands, that open onto the skin surface near the vent or on the thigh. ${ }^{9-11}$ These organs typically produce secretions that protrude through pores as solid plugs.
They are most active in males during the mating season and generally are believed to produce pheromones for sexual signaling and/or territorial scent marking. ${ }^{8,47}$

TLC analyses of the preanal gland secretions of the Indian house lizard (Hemidactylus flaviviridis, Gekkonidae) and Hardwick's spiny-tailed lizard (Uromastix hardwickii, Agamidae), both obtained commercially, suggested the presence of FFAs, triacylglycerols, wax esters, sterols and their esters, and phospholipids in males of both species. Only the last three compound classes were observed in female spiny-tailed lizards; female house lizards lack preanal glands. ${ }^{48}$ Histochemical studies of males of both lizards revealed that the lipid content and various enzymatic activities in the glandular tissues and/or secretions peak during the mating season. ${ }^{49-51}$ An increase in enzyme activity associated with the citric acid cycle may reflect enhanced lipogenesis via acetyl CoA carboxylase. ${ }^{51}$

The femoral gland secretions of males of the green iguana (Iguana iguana), a neotropical herbivorous iguanid, were found to contain FFAs and/or esterified fatty acids with chain lengths between $\mathrm{C}_{14}$ and $\mathrm{C}_{26}$; the steroids 3 , epicoprostanol (4), 6 , lanosterol (29), 33, 43, stigmasterol (46); and TLC components consistent with triacylglycerols, methyl esters, steryl esters, and phospholipids. ${ }^{52,53}$ The steroids 33, 43, and 46 and their respective esters comprise about $10 \%$ of the total glandular lipids. These typical phytosterols may be derived from the diet. $^{53}$

Alberts et al. ${ }^{53}$ found that the femoral gland secretions of male green iguanas during the mating season contain an elevated lipid content and a greater abundance of unsaturated acids among the FFAs, triacylglycerols, and methyl esters. This seasonal variation may enhance the volatility, and thus the detectability, of scent deposits. The sterol content of the secretions and, to a lesser degree, that of the acids vary among individuals. A qualitative comparison of femoral gland lipids from juvenile and adult green iguanas failed to indicate differences between them, however, these age classes differed by only one year. ${ }^{52}$

The femoral gland secretions of males of the Iberian rock lizard (Lacerta monticola cyreni), a montane lacertid from the Iberian Peninsula, contain 1, $\mathrm{C}_{6}-\mathrm{C}_{22}$ FFAs, $\mathrm{C}_{18}-\mathrm{C}_{26}$ primary alcohols, methyl decanoate, methyl eicosanoate, ethyl hexadecanoate, isopropyl dodecanoate and tetradecanoate, as well as the lactone 4-hexadecanolide (74). The steroids present include 6, cholesta-2,4-diene (12), 13, 14, 33, ergosta-5,8-dien3-ol (37), ergosta-5,22-dien-3-ol (39), ergosterol (41), $\gamma$-sitosterol (44), stigmasta-5,24(28)-dien-3-ol (47), 24-propylidenecholest5-en-3-ol (49), and several 4,4-dimethyl triterpenoids such as lanost-8-en-3-ol (28), 4,4-dimethylcholest-7-en-3-ol (30), 4,4-dimethylcholesta-5,7-dien-3-ol (31), as well as cholesta-5,7dien-3-ol (15 dehydrocholesterol), a precursor of vitamin $\mathrm{D}_{3}$ that is essential for calcium uptake and bone deposition. ${ }^{54-56}$ Alkanes also may be present. ${ }^{54}$

The concentrations of some femoral gland components in male rock lizards are positively correlated with features associated with social dominance and mate attractiveness. ${ }^{55,56}$ For example, large males contain high proportions of sterols, such as $\mathbf{6 , 3 3}$, and 44, as well as some FFAs, such as nonanoic, decanoic, and octadecanoic acids. High quality males, identified experimentally by their superior T-cell-mediated immune response and other indicators, were found to contain high proportions of $\mathbf{1 5}$ and $\mathbf{4 1}$ 
in their secretions. The concentration of $\mathbf{1 5}$ increased in males receiving it as a dietary supplement. ${ }^{57}$

Female rock lizards exhibited heightened tongue flicking to cotton swabs treated with the secretions of males containing high amounts of $\mathbf{1 5}$ and $\mathbf{4 1}$ and to swabs treated with solutions of these authentic compounds. ${ }^{56,57}$ Females also were attracted to areas scent-marked by these males, thus implicating $\mathbf{1 5}$ and $\mathbf{4 1}$ in mediating mate choice. Cholesterol (6) in the secretions of male rock lizards reportedly signals their fighting ability. ${ }^{\mathbf{5 8}}$

The femoral gland secretions of male Psammodromus algirus, a Mediterranean lacertid inhabiting forests and pastures, were found to contain squalene (1), $\mathrm{C}_{16}$ and $\mathrm{C}_{19}$ alkanes, FFAs with chain lengths between $\mathrm{C}_{8}$ and $\mathrm{C}_{22}$, as well as methyl eicosatetraenoate, hexadecyl octadecenoate, octadecyl hexadecenoate, 1-octanol, a bishomologous series of $\mathrm{C}_{16}-\mathrm{C}_{22}$ primary alcohols, as well as saturated and unsaturated $\mathrm{C}_{7}-\mathrm{C}_{12}$ aldehydes, 72, and $74 .{ }^{59}$ The steroids present include $6,13,15$, cholesta-5,22-dien-3-ol (17), cholesta-4-en-3-one (22), 4-methylcholest-7-en-3-ol (26), 27, lanost-8-en-3-ol (28), 29, 30, 31, 33, 34, $\gamma$-ergostenol (36), 37, 39, ergosta-7,22-dien-3-ol (40), 41, 44, stigmast-7-en-3-ol (45), and 46. Campesterol (33) is the chief sterol in the glandular secretions of Psammodromus algirus, whereas $\mathbf{6}$ is the primary sterol in the secretions of many other lizards. Most of the compounds identified in this species occur in both juveniles and adults; however, the two wax esters listed above occur only in adults and 22 occurs only in juveniles. Martin and López ${ }^{59}$ postulated that conspecifics derive information on the age of males from the proportions of these compounds in their secretions.

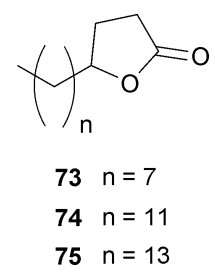

The femoral gland secretions of males of Schreiber's green lizard (Lacerta schreiberi), which occurs in moist, woody habitats of the Iberian Peninsula, contain 1, $\mathrm{C}_{9}-\mathrm{C}_{22}$ FFAs, $\mathrm{C}_{12}-\mathrm{C}_{24}$ alcohols, 2-pentadecanone and 2-hexadecanone, 72, methyl 4-hydroxyoctadenanoate, ethyl eicosatetraenoate, and $\gamma$-lactones of $\mathrm{C}_{16}$ and $\mathrm{C}_{18}$ hydroxy acids. ${ }^{60}$ The steroids present include $3,6,8,13,19$, cholestan-3-one (21), cholesta-3,5-dien-7one (25), 26, 27, 4,4-dimethylcholesta-8,14-dien-3-ol (32), 33, 34, 36, ergost-22-en-3-ol (38), 44, 45, 3,11-dihydroxypregnan-20-one (50), and 20-methylpregn-20-en-3-ol (51).

The femoral gland secretions of male Iberian wall lizards (Podarcis hispanica, Lacertidae) and common wall lizards (Podarcis muralis), both collected in Spain, contain squalene (1), and tetramethylhexadecapentaene, probably the diterpene $\beta$-springene (129), FFAs and alcohols with chain lengths between $\mathrm{C}_{8}$ and $\mathrm{C}_{29}$ and several wax-type esters comprised of them, ethyl and isopropyl esters, 72, nonanal, nonadecanone, and $74 .^{61}$ The steroids present include $\mathbf{3}, \mathbf{6}$, cholest-5-en-3-yl acetate $(\mathbf{8}), \mathbf{1 3}, \mathbf{1 4}$, 15, 16, 22, cholesta-4,6-dien-3-one (24), 31, 33, 34, 37, 41, 44, 46, and 49. Forty of seventy compounds are shared by both species. Twenty compounds are unique to Iberian wall lizards, while eight compounds are unique to common wall lizards.
Female wall lizards in choice tests preferred the scent of males whose secretions contained a high content of $\mathbf{1 5}$ and a low content of $\mathbf{6}^{62}$ The proportions of $\mathbf{1 5}$ in the secretions of males correlated positively with their T-cell-mediated immune response, suggesting that this compound denotes high quality potential mates.

The femoral gland secretions of males of the spiny-footed lizard (Acanthodactylus erythrurus), a lacertid that inhabits dry, sparsely vegetated habitats in Western Europe, contain 1, $\mathrm{C}_{9}-\mathrm{C}_{20}$ FFAs, $\mathrm{C}_{10}-\mathrm{C}_{29}$ alcohols, $\mathrm{C}_{13}$ and $\mathrm{C}_{19}$ ketones, hexadecyl hexadecenoate and octadecyl octadecenoate, a $\mathrm{C}_{18}$ hydroxylated methyl ester, ethyl eicosatetraenoate, isopropyl tetradecanoate, 72, and the $\gamma$-lactones 4-dodecanolide (73), 74, and 4-octadecanolide (75). ${ }^{63}$ FFAs with chain lengths between $\mathrm{C}_{9}$ and $\mathrm{C}_{15}$ were observed chiefly in subadult males, whereas $\mathrm{C}_{9}$ and $\mathrm{C}_{15}$ were observed chiefly in adults. López and Martin ${ }^{63}$ suggested that the higher molecular weight acids in adult lizards enhance the persistence of their territorial scent marks in the dry environments they inhabit. The steroids present include 6, 13, 16, 31, 33, 37, 44, and 15 and its acetate 20.

Environmental variables may influence the nature of chemicals used as pheromones by terrestrial vertebrates. ${ }^{64}$ Higher temperatures, of course, increase the rate at which compounds evaporate from scent marks, thus selecting for higher molecular weight semiochemicals. Humidity also may influence volatility.

Martin and López ${ }^{61}$ investigated the possible influence of habitat humidity on the femoral gland chemistry of Iberian wall lizards. Lizards from one population (type 1) that typically occurs in the humid highlands of northwestern Iberia were compared with those from a population (type 2) that typically occurs in the arid Mediterranean region of central and southern Iberia. The lizards used in this study were from overlapping populations in central Spain. Type 1 males were found to possess twelve compounds not detected in type 2 males, including wax esters. Martin and López concluded that the different chemical profiles of the two lizard types are related to the different climatic conditions of the geographic areas they occupy, where less volatile and more stable femoral gland compounds occur in humid habitats. However, the subjects used by Martin and López originated from the same area. The adaptive significance of the contrasting lipid profiles of these lizards, therefore, is unclear, unless gene flow or other mitigating circumstances prevail.

The precloacal gland secretions of twenty Chilean lizards of the genus Liolaemus (Tropiduridae) collectively contain $\mathrm{C}_{10}-\mathrm{C}_{29}$ alkanes, butanedioic and hexanedioic acids, as well as lactic acid. ${ }^{65,66}$ Fatty acids with chain lengths between $\mathrm{C}_{6}$ and $\mathrm{C}_{26}$, and some methyl esters derived from them, are also present. The steroids present include 3, 5, 6, 11, 41, and 43. Cholesterol and $\mathrm{C}_{14}-\mathrm{C}_{18}$ FFAs and/or esterified fatty acids occur in all species. One species examined in detail, Liolaemus bellii, was found to exhibit individual variation among the alkanes, carboxylic acids, and sterols in the secretions, prompting Escobar et al. ${ }^{65}$ to postulate that precloacal glands secrete self-recognition pheromones.

A comparison of two genetically distinct populations of Liolaemus fabiani inhabiting the Atacama Salt Flat in Chile revealed minor populational differences in precloacal gland lipids. ${ }^{66}$ Cholesterol and hexanoic acid, the most volatile acid observed in this species, are more abundant in the population 
exposed to higher temperatures. Escobar et al. ${ }^{66}$ proposed that 6 acts as an unreactive matrix, reducing the volatilization or degradation of secretion-borne semiochemicals, thus preventing their loss at high temperatures.

They also hypothesized that Liolaemus spp. occupying higher elevations and lower latitudes adapt to these environments by producing more precloacal gland secretions and/or less volatile secretion components. ${ }^{65}$ They observed that the number of precloacal gland pores present in Liolaemus spp. correlated positively with elevation and negatively with latitude. Escobar et al. concluded that lizards adapt to harsh environments by producing more secretions, although they did not measure secretion output in their comparative study. Furthermore, comparisons among forty-nine compounds from the twenty Chilean lizard species they analyzed failed to indicate correlations between secretion composition and environmental variables.

Recently, the femoral gland secretions of the sungazer (Cordylus giganteus, Cordylidae), a large lizard endemic to South African grasslands, were found to contain 1, pentacosane, $\mathrm{C}_{14}-\mathrm{C}_{24}$ FFAs, 1-dodecanol and 1-hexadecanol, 2-heptadecenal, a bishomologous series of $\mathrm{C}_{17}-\mathrm{C}_{25}$ methyl ketones, dodecyl propanoate, dodecyl acrylate and $72 .{ }^{67}$ The steroids present include 6, 15, 22, 28, 29, ergost-5-en-3 $\beta$-ol (35), and 43.

The chief products of femoral glands are proteins. ${ }^{68-70}$ In the desert iguana (Dipsosaurus dorsalis) from California, for example, proteins comprise $c a .80 \%$ of the glandular exudate. ${ }^{68}$ An analysis by gel electrophoresis of the femoral gland secretions of sixteen lizard species representing five families revealed a total of forty-eight protein components ranging from $6 \mathrm{kDa}$ to 104 $\mathrm{kDa}$. Gel banding patterns generally reflected taxonomic, i.e., subfamilial, affinities, ${ }^{69}$ but ecological factors such as substrate type, climate, and diet also may influence secretion composition. For example, the display of similar femoral gland proteins among several saxicolous sceloporine lizards may reflect convergence with respect to scent marking on rocky substrates. The desert iguana and the green iguana were found to exhibit intraspecific variation in femoral gland secretions that could be used in sexual, clutch, and/or individual recognition. ${ }^{68-70}$ Behavioral studies have demonstrated that male green iguanas use chemoreception to detect femoral gland proteins experimentally deposited on the substrate. ${ }^{71}$ Detailed information on the identity of the signaler may be derived from these nonvolatile exudates when conspecifics investigate them by tongue flicking.

3.2.2 Urodeal gland. Female lizards of the Cordylidae, Scincidae, and other families possess tubular organs called urodeal glands that empty into folds of the urogenital chamber, the urodeum, via small orifices. ${ }^{9,10,72}$ These glands are active during the breeding season and are thought to discharge pheromones from the cloaca that elicit courtship in males. ${ }^{72-74}$

Male broad-headed skinks (Plestiodon laticeps) presented with fractionated extracts of urodeal glands excised from estradioltreated females exhibited more tongue flicks to neutral lipids than to other fractions. ${ }^{74}$ TLC fractionation of these lipids revealed bands consistent with steryl and wax esters and mono-, di- and triacylglycerols. Inconclusive results, however, were obtained in behavioral tests of testosterone-treated male skinks presented with TLC fractions.
3.2.3 Caudal gland. The caudal gland of Australian geckos of the genus Diplodactylus consists of a series of chambers deeply embedded in the tail. ${ }^{75,76}$ Sticky fluids from this gland exude onto the skin surface through numerous rupture zones and may be squirted up to $50 \mathrm{~cm}$ when geckos are provoked. ${ }^{76}$ The chief defensive value of these exudates appears to derive from their stickiness and the consequent physical impairment of predatory arthropods. ${ }^{76}$ The odor of the caudal gland secretions, which in the western spiny-tailed gecko (Diplodactylus spinigerus) reportedly is reminiscent of the scent of crushed legume seeds, ${ }^{76}$ also may deter predators. Chickens, for example, rejected mealworms treated with these secretions. ${ }^{75}$

Gel electrophoresis of the secretions of the spiny-tailed gecko (Diplodactylus ciliaris), Rankin's spiny-tailed gecko (Diplodactylus rankini), and the silver spiny-tailed gecko (Diplodactylus strophurus) revealed in each species three major proteins of masses $\mathrm{ca} .30,45$, and $80 \mathrm{kDa} .{ }^{77}$ Only the $80 \mathrm{kDa}$ component of the silver spiny-tailed gecko reacted positively for glycoprotein.

\subsection{Snakes}

3.3.1 Scent gland. All snakes possess in the base of their tail a pair of elongate sacs known as scent glands that open through two ducts exiting at the posterolateral margin of the vent., ${ }^{9,10,78}$ Snakes typically discharge malodorous secretions from these glands when provoked. Some snakes, including rattlesnakes (Crotalus spp.) and some other crotalines, defensively spray scent gland fluids. ${ }^{79}$

Scent gland secretions are widely thought to deter predators, ${ }^{7}$ a contention supported by observations of aversive responses by ants, ${ }^{80}$ ophiophagous snakes,${ }^{81}$ crocodylians, ${ }^{82}$ and carnivores. $^{83-85}$ The increased size of scent glands in females ${ }^{78}$ and the greater pungency of their secretion prompted Kissner et al. ${ }^{86}$ to suggest that females depend more heavily on these organs for antipredator defense. Greene and Mason, ${ }^{87}$ on the other hand, demonstrated that the secretions of female brown treesnakes inhibit male courtship, serving to reject unpreferred suitors. Scent glands also are hypothesized to produce alarm pheromones. ${ }^{88}$

Oldak personally discriminated among a number of snakes on the basis of the species-peculiar odors of scent gland secretions. ${ }^{89}$ $\mathrm{He}$ attributed some distinctive odors to particular lipids fractionated by TLC. For example, a band of the pinesnake (Pituophis melanoleucus) eluted from the triacylglycerol zone possessed an odor identical to that of the raw secretion. Oldak's ${ }^{89}$ or other TLC studies ${ }^{\mathbf{1 8 9 0 , 9 1}}$ suggest that scent gland lipids include hydrocarbons, FFAs, methyl esters, wax esters, sterols and their esters, phospholipids, and mono-, di- and triacylglycerols. Taxonomic, ${ }^{18,89,90}$ sexual, ${ }^{89,91}$ (minor) individual, ${ }^{18}$ and ontogenetic $^{89}$ variation in secretion composition have been described. Tolson's analysis of the scent gland lipids of West Indian boids of the genus Epicrates revealed TLC components in insular populations of Antillean species that are absent in a continental congener, the rainbow boa (Epicrates cenchria). ${ }^{18}$ Tolson suggested that Antillean snakes evolved new glandular compounds for defense as they dispersed and encountered new predators.

$\mathrm{C}_{12}-\mathrm{C}_{26}$ FFAs and/or 6 are known from the scent glands of boid, ${ }^{91,92}$ elapid, ${ }^{19}$ leptotyphlopid, ${ }^{93}$ and viperid snakes. ${ }^{79,94,95}$ 
FFAs in the secretions of the Texas blindsnake (Leptotyphlops dulcis) may deter attacks by ants when it enters ant colonies to feed. ${ }^{93} \mathrm{C}_{16}$ and $\mathrm{C}_{18}$ FFAs usually predominate in scent gland secretions. However, $\mathrm{C}_{20}-\mathrm{C}_{22}$ compounds are the most abundant acids observed in two crotaline snakes, the mamushi (Gloydius blomhoffiii) ${ }^{94}$ and the western diamondback rattlesnake (Crotalus atrox) ${ }^{79}$

Alkylglycerol monoethers were identified in the secretions of the western diamondback rattlesnake. ${ }^{95}$ Males and females of this species possess $1-O$-monoalkylglycerols with $\mathrm{C}_{12}-\mathrm{C}_{20}$ side chains, the most abundant being 1- $O$-hexadecylglycerol. A TLC analysis of the eastern diamondback rattlesnake (Crotalus adamanteus) and the Florida water moccasin (Agkistrodon piscivorus conanti), however, failed to indicate bands in the zone where glycerol monoethers were expected. ${ }^{90}$

The volatile compounds from the scent glands of boid, colubrid, crotaline, and/or elapid snakes include phenol, 3-methylbutanal, and acetic, propanoic, 2-methylpropanoic, butanoic, 2-methylbutanoic, 3-methylbutanoic, methylbenzoic, phenylacetic, and 3-phenylpropanoic acids, all of which are strongly odorous. ${ }^{19,79,96}$ 2-Lactic acid occurs in Dumeril's ground boa (Acrantophis dumerili), along with $\mathbf{1}$ and unknown terpenoids. ${ }^{91}$

The nitrogenous compounds from the scent glands include trimethylamine (in boids and colubrids) and 2-piperidone (in boids and viperids). ${ }^{96}$ Even-numbered fatty amides ranging from $\mathrm{C}_{16}-\mathrm{C}_{22}$ and $\mathrm{C}_{18}-\mathrm{C}_{24}$ occur in Dumeril's ground boa ${ }^{91}$ and the western diamondback rattlesnake, ${ }^{79}$ respectively. Three additional compounds from the ground boa were characterized tentatively as amines. ${ }^{91}$

Only about $6 \%$ of the scent gland secretions is amenable to extraction with organic solvents, suggesting that the bulk of these exudates consists of macromolecules. ${ }^{91,92}$ Studies by gel electrophoresis or gel filtration chromatography (GFC) of thirtytwo snake species representing seven families demonstrated one to eight protein components per species, with molecular masses ranging from $10 \mathrm{kDa}$ to $100 \mathrm{kDa} .{ }^{19,97}$ The Texas blindsnake possesses a glycoprotein containing glucosamine, galactosamine, and seventeen different amino acids. ${ }^{93}$ This glycoprotein is unusual in lacking tyrosine, a moderately reactive amino acid prone to oxidation and oxidative cross-linking.

Analyses of proteins in the secretions, as suggested by some investigators for scent gland lipids, ${ }^{\mathbf{1 8 , 8 9}}$ may furnish information relevant to snake systematics. ${ }^{97,98}$ Weldon and Leto, ${ }^{97}$ for example, noted a $30 \mathrm{kDa}$ component resolved by gel electrophoresis that appeared in the boids they examined, but not in the related pythonids. Investigations of these or other skin products may corroborate proposed phylogenetic schemes established by more rigorous molecular methods.

3.3.2 Nuchal gland. Ten species of Asian natricine snakes of the genera Balanophis, Macropisthodon, and Rhabdophis possess one or more paired secretory sacs called nuchal glands situated under the dorsal skin of the anterior trunk. ${ }^{99,100}$ These organs, unlike most integumental glands, arise embryologically from mesoderm rather than ectoderm. ${ }^{101}$ Nuchal glands discharge secretions, sometimes spraying them, when they rupture from pressure applied to overlying skin. ${ }^{99,102}$ The yamakagashi (Rhabdophis tigrinus), a species widespread in eastern Asia, occasionally exudes these fluids onto its dorsum when it assumes a peculiar arched-neck defensive posture. ${ }^{102}$

The nuchal gland secretions of the yamakagashi are noxious to mammalian predators. ${ }^{100}$ The raw glandular exudates experimentally applied to the eyes of dogs and rabbits caused pupillary miosis and corneal detachment. ${ }^{103}$ In vitro toxicity studies using mammalian kidney and heart preparations demonstrated that bufadienolides in the secretions inhibit $\mathrm{Na}^{+}+$ $\mathrm{K}^{+}$) ATPase and are positively inotropic, ${ }^{104}$ which are typical properties of these compounds.

A number of bufadienolides have been identified from the yamakagashi. ${ }^{104-107}$ Several compounds, including 76, 81, 92 and 93, are present in the red-necked keelback (Rhabdophis subminiatis) from Thailand, but the skin of Pryer's keelback (Amphiesma pryeri), a Japanese natricine that lacks nuchal glands, does not contain them. ${ }^{106}$ Gamabufotalin (82) and other nuchal gland compounds also occur in the parotoid gland secretions of toads (Bufo spp.), which are preyed upon by yamakagashis.

Cholesterol (6), the metabolic precursor of bufadienolides, occurs in the nuchal glands of the yamakagashi. ${ }^{107}$ Mori and Burghardt, ${ }^{108}$ however, postulated that this snake acquires these compounds from toads, sequestering them from their prey for defense against their predators. Hutchinson et al. ${ }^{107}$ investigated this hypothesis by comparing the nuchal gland fluids of wildcaught snakes from areas in Japan inhabited by toads with fluids from snakes inhabiting Kinkazan Island, where toads are absent. All snakes except those from Kinkazan possessed bufadienolides 76-95. Laboratory studies demonstrated that hatchling yamakagashis, even those from Kinkazan, rapidly and consistently accumulated bufadienolides in their nuchal glands when reared on North American toads (Bufo fowleri and B. terrestris), but not on prey (fish or frogs) that lack these compounds. ${ }^{107}$ The toads contain mostly the conjugated bufadienolides 96-103 and 82. Yamakagashis that were fed toads accumulated 76-78, 83, 86-88, and 91 in their nuchal glands, none of which they possessed upon hatching. These results betoken the potential influence of local prey availability on the defensive chemistry of the yamakagashi. Moreover, the unfed progeny of wild-caught dams that possessed large amounts of bufadienolides contained correspondingly high levels of these compounds, raising suspicion that females prenatally provision their offspring with these defensive toxins. ${ }^{107}$

The yamakagashi may sequester some bufadienolides, such as 82, unaltered or after hydrolyzing their substituted arginine side chains, e.g., 82 from 102, 88 from 101, and 91 from 103. ${ }^{107}$ Most of the nuchal gland bufadienolides, however, appear to have been hydroxylated after dietary uptake, an alteration that may enhance their bioavailability and/or toxicity.

Riboflavin (vitamin $\mathrm{B}_{2}$ ), another presumed dietary component, occurs in the nuchal glands of the yamakagashi. ${ }^{106}$ Riboflavin also is known to impart a yellow hue to the skins of some boid, colubrid, and elapid snakes. ${ }^{109}$

3.3.3 Nasal gland. Some colubrid snakes of the subfamily Psammophiinae, primarily African species, possess a paired gland situated lateral to the nasal cavity, opening through ducts near the external nares. ${ }^{\mathbf{1 1 0 , 1 1 1}}$ Snakes spread secretions from this nasal gland over their body via "skin polishing," where they rub 


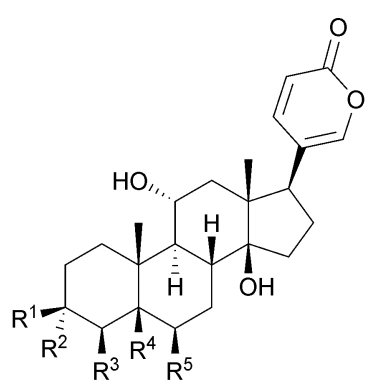<smiles>C[C@@]12C[C@H](O)[C@H]3[C@](O)(CC[C@@]4(O)CC(=O)CC[C@]34C)[C@@]1(C)CC[C@H]2c1ccc(=O)oc1</smiles>

86

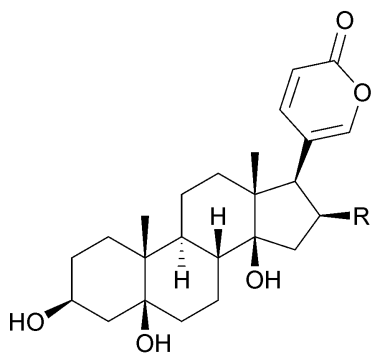

$90 \mathrm{R}=\mathrm{OH}$

$91 \mathrm{R}=\mathrm{H}$
$76 \mathrm{R}^{1}=\mathrm{H}, \mathrm{R}^{2}=\mathrm{OH}, \mathrm{R}^{3}=\mathrm{H}, \mathrm{R}^{4}=\mathrm{OH}, \mathrm{R}^{5}=\mathrm{H}$

$77 \mathrm{R}^{1}=\mathrm{H}, \mathrm{R}^{2}=\mathrm{OH}, \mathrm{R}^{3}=\mathrm{H}, \mathrm{R}^{4}=\mathrm{H}, \mathrm{R}^{5}=\mathrm{OH}$

$78 \mathrm{R}^{1}=\mathrm{OH}, \mathrm{R}^{2}=\mathrm{H}, \mathrm{R}^{3}=\mathrm{OH}, \mathrm{R}^{4}=\mathrm{H}, \mathrm{R}^{5}=\mathrm{H}$

$79 \mathrm{R}^{1}=\mathrm{OH}, \mathrm{R}^{2}=\mathrm{H}, \mathrm{R}^{3}=\mathrm{H}, \mathrm{R}^{4}=\mathrm{OH}, \mathrm{R}^{5}=\mathrm{OH}$

$80 R^{1}=\mathrm{OH}, \mathrm{R}^{2}=\mathrm{H}, \mathrm{R}^{3}=\mathrm{H}, \mathrm{R}^{4}=\mathrm{H}, \mathrm{R}^{5}=\mathrm{OH}$

$81 \mathrm{R}^{1}=\mathrm{OH}, \mathrm{R}^{2}=\mathrm{H}, \mathrm{R}^{3}=\mathrm{H}, \mathrm{R}^{4}=\mathrm{OH}, \mathrm{R}^{5}=\mathrm{H}$

$82 R^{1}=O H, R^{2}=H, R^{3}=H, R^{4}=H, R^{5}=H$

$83 R^{1}=H, R^{2}=O H, R^{3}=H, R^{4}=H, R^{5}=H$

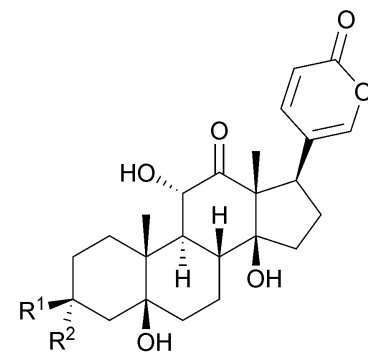

$84 \mathrm{R}^{1}=\mathrm{H}, \mathrm{R}^{2}=\mathrm{OH}$

$85 R^{1}=O H, R^{2}=H$<smiles>C[C@@]12C3[C@@H](O)C[C@]4(C)[C@H](c5ccc(=O)oc5)CC[C@]4(O)[C@@H]3CC[C@@H]1C[C@H](O)C[C@@H]2O</smiles>

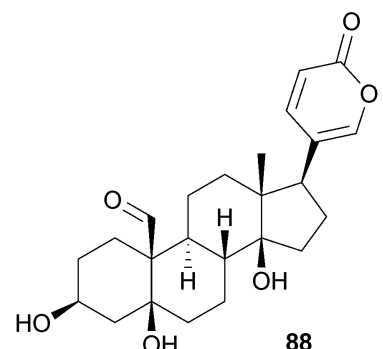

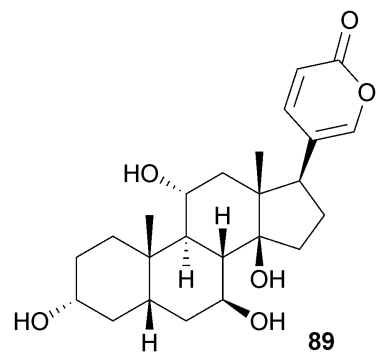

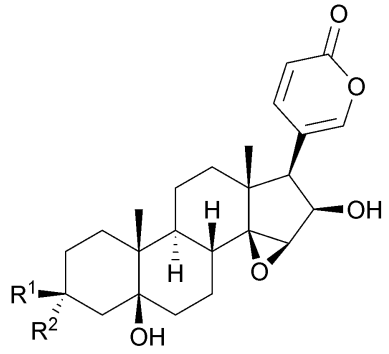

$92 \mathrm{R}^{1}=\mathrm{OH}, \mathrm{R}^{2}=\mathrm{H}$

$93 \mathrm{R}^{1}=\mathrm{H}, \mathrm{R}^{2}=\mathrm{OH}$<smiles>C[C@]12CC[C@H]3[C@@H](CC[C@@]4(O)C[C@H](O)CC[C@]34C)C1=C[C@H](O)[C@H]2c1ccc(=O)oc1</smiles>

94

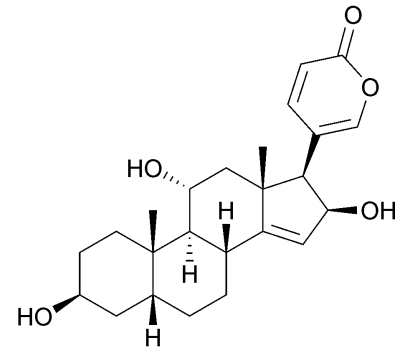

95 their snout along their dorsal and ventral skin surfaces. Nasal gland fluids, which dry to form to a lusterless film on the skin, are hypothesized to retard evaporative water $\operatorname{loss}^{110}$ or to contain pheromones used to scent-mark conspecifics and/or territories. ${ }^{111}$
The watery nasal gland secretions of the Montpellier snake (Malpolon monspessulanus), an inhabitant of xeric Mediterranean habitats, contain proteins, electrolytes, and lipids, including $\mathrm{C}_{16}$ and $\mathrm{C}_{18}$ FFAs. ${ }^{110}$

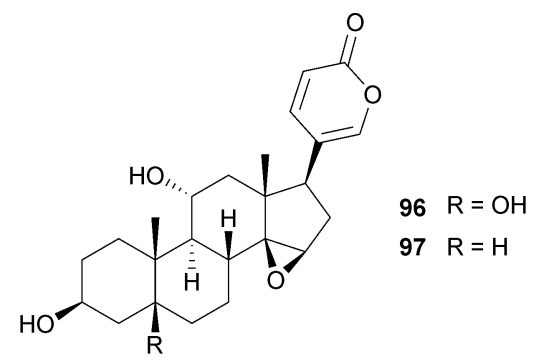

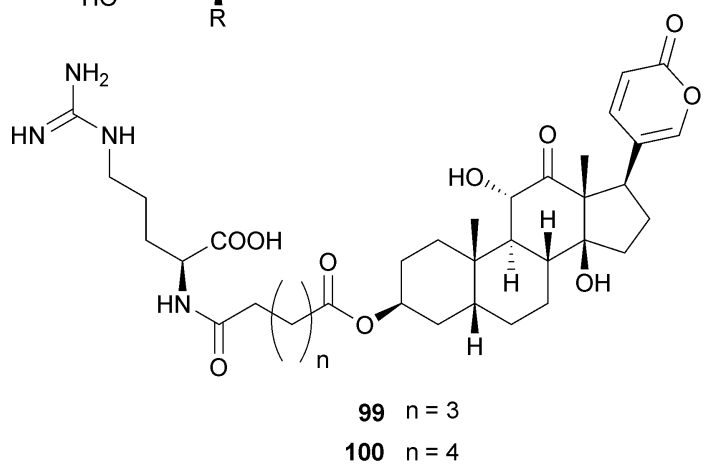




\section{Cloacal gland: Rhynchocephalia}

The Rhynchocephalia is represented by two extant species of tuatara, Sphenodon punctatus and Sphenodon guentheri, longlived ( $>60$ years), lizard-like inhabitants of more than 30 islands near New Zealand. Tuatara possess a paired gland that opens on both sides of the cloacal margin. ${ }^{9}$ This gland is believed to produce pheromones, although the involvement of chemical cues in the social interactions of tuatara is unclear. ${ }^{112}$

Methylene chloride extracts of the cloacal gland secretions of adult male and female Sphenodon punctatus were found to contain unusual triacylglycerols mainly comprised of two or three acyl groups derived from the following medium chain-length acids: octanoic (104), ( $Z$ )-4-octenoic (105), (4E,6Z)-4,6-octadienoic (106), 2,6-dimethyl-5-heptanoic (107), 2,6-dimethyl-5-heptenoic (108), 3,7-dimethyl-6-octenoic (109), (Z)-4-decenoic (110), (4Z,7Z)-4,7-decadienoic (111), 4,8-dimethyl-7-nonenoic (112), 2,6,10-trimethyl-9-undecenoic (113), and (E)-2,6,10-trimethyl5,9-undecadienoic acids (114). ${ }^{113}$ Glycerides containing the common $\mathrm{C}_{16}$ and $\mathrm{C}_{18}$ acids also are present, but not together with

\section{4-114.}

Epithelial cells within the cloacal gland stain positively for carbohydrates likely associated with glycoproteins. ${ }^{9}$ Analyses by gel electrophoresis and matrix-assisted laser desorption ionization mass spectrometry (MALDI-MS) of the secretions of male and female Sphenodon punctatus revealed a major glycoprotein with a molecular mass of $c a .50 \mathrm{kDa} .{ }^{114}$

\section{Testudines}

\subsection{Rathke's gland}

All extant turtles except the Testudinidae (tortoises) and some emydine genera possess one or more pairs of Rathke's gland, an oval-shaped organ situated outside the peritoneal cavity, adpressed to the internal lateral aspect of the shell. ${ }^{115,116}$ Ducts from this gland pass through bones and/or scutes and open through pores on the shell bridge or the skin of the axillary or inguinal regions. ${ }^{115-117}$ Turtles exude Rathke's gland fluids, in some cases spraying them, when provoked. ${ }^{115}$ Rathke's gland appears to be more active in young turtles. ${ }^{118,119}$ This organ is hypothesized to discharge predator repellents, ${ }^{116,120}$ pheromones, ${ }^{121}$ or excreted metabolites. ${ }^{122}$
An analysis of the Australian snake-necked turtle (Chelondina longicolla), the sole pleurodire investigated for Rathke's gland lipids, revealed common saturated and unsaturated $\mathrm{C}_{16}$ and $\mathrm{C}_{18}$ acids, 109, and $\beta$-ionone (115). ${ }^{123}$ On the other hand, the North American stinkpot turtle (Sternotherus odoratus), which is named for its malodorous secretions, was found to contain phenylacetic, 3-phenylpropanoic, 5-phenylpentanoic, and 7-phenylheptanoic acids (116), and lesser amounts of 3-methylbutanoic, hexanoic, hexadecanoic, and heptadecanoic acids. ${ }^{124}$ Phenylacetic acid occurs in the Rathke's gland secretions of other cryptodires, ${ }^{125,126}$ but the other $\omega$-phenylalkanoic acids have not been reported elsewhere from nature.<smiles>CC(=O)/C=C/C1=C(C)CCCC1(C)C</smiles><smiles>CCCC(C)C(=O)O</smiles>

Eisner et al. ${ }^{124}$ tested the stinkpot turtle's secretion as a feeding deterrent by topically treating beetle larvae with a mixture of $\omega$-phenylalkanoic acids and offering them as food to swordtail fish (Xiphophorus helleri). This fish is only $c a .10 \mathrm{~cm}$ long and does not pose a threat to turtles. Swordtails were only mildly averse to the acid mixture. Eisner et al. suggested that $\omega$-phenylalkanoic acids act as aposematic cues, denoting the distastefulness, pugnacity or other undesirable features of stinkpot turtles to potential predators.

TLC analyses of loggerhead (Caretta caretta) ${ }^{\mathbf{1 2 2}}$ and Kemp's ridley sea turtles (Lepidochelys kempi) ${ }^{125}$ have revealed bands in secretion extracts consistent with FFAs, triacylglycerols, methyl esters, sterols and their esters, and phospholipids. GC-MS analyses of these marine turtles and a freshwater species, the North American mud turtle (Kinosternon subrubrum), ${ }^{126}$ demonstrated the presence of short-chain diacids such as ethanedioic, butanedioic, pentanedioic, and 2-methylpropanedioic acids, the 2-ketoacids 2-oxopropanoic, 2-oxobutanoic, 2-oxo-3methylpentanoic, 2-oxo-4-methylpentanoic, and 2-oxopentanedioic acids, as well as benzoic, hydroxyacetic, hydroxybutanoic, lactic, 2,3-dihydroxypropanoic, phenylacetic, and 4-hydroxyphenylacetic acids. ${ }^{122,125,126}$ In addition, methyl succinate, common $\mathrm{C}_{14}-\mathrm{C}_{26}$ fatty acids, the steroids $\mathbf{6}$ and $\mathbf{2 2}$, undecanal, and glyceraldehyde (117) are present among these species.

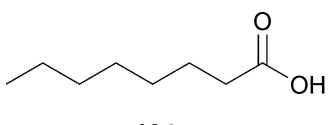

104<smiles>CC(C)=CCCC(C)C(=O)O</smiles>

108<smiles>CC(C)=CCCC(C)CCC(=O)O</smiles>

112

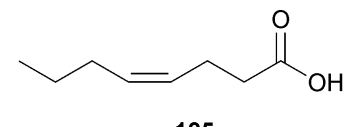

105

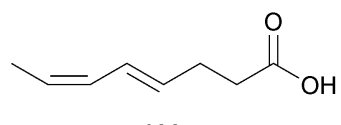

106<smiles>CC(C)CCCC(C)C(=O)O</smiles>

107<smiles>CCCCCC/C=C/CCC(=O)O</smiles>

109<smiles>CC(C)=CCCC(C)CCCC(C)C(=O)O</smiles><smiles>CCC=CCC=CCCC(=O)O</smiles><smiles>CC(C)=CCC/C(C)=C/CCC(C)C(=O)O</smiles> 
<smiles>O=CC(O)CO</smiles>

117

Lactic acid is a major constituent in the Rathke's gland secretions, ${ }^{122,125,126}$ attaining concentrations in Kemp's ridley sea turtles of $2.4 \mathrm{mg} \mathrm{ml}^{-1} .{ }^{125}$ Weldon and Tanner ${ }^{122}$ postulated that this gland functions to excrete this and possibly other bloodborne metabolites. Measurements of the volumes of fluids released from juvenile marine turtles indicated that up to $2 \mathrm{mg}$ of lactic acid can be expelled at once. ${ }^{118}$ The physiological significance of this observation, however, is unclear, pending studies on the rate of secretion replenishment.

The chief products of Rathke's glands are proteins. ${ }^{116,123,124}$ In loggerhead and Kemp's ridley sea turtles, Rathke's gland fluids contain $20 \mathrm{mg} \mathrm{ml}^{-1}$ and $10 \mathrm{mg} \mathrm{ml}^{-1}$ of protein, respectively. ${ }^{127}$ Two protein fractions were resolved by GFC in both species. The primary component has a mass of $55 \mathrm{kDa}$ and the smaller component has a mass of $>100 \mathrm{kDa}$. The $55 \mathrm{kDa}$ components of these two turtles are glycoproteins containing glucosamine. They exhibit similar amino acid compositions and are identical for the first $15 \mathrm{~N}$-terminal residues. ${ }^{\mathbf{1 2 7}}$ Characterizations of disulfide bonds and $N$-glycolsylation sites of the $55 \mathrm{kDa}$ glycoprotein from Kemp's ridley sea turtle link it to an esterase/lipase family that includes catalytic (esterase) and noncatalytic (thyroglobulin) members. ${ }^{128}$

A comparison by gel electrophoresis of the Rathke's gland secretions of Kemp's ridley sea turtle and the mud turtle suggested that they possess similar protein profiles. ${ }^{\mathbf{1 2 6}}$ An analysis by MALDI-MS of the secretions of twenty-seven turtle species (13 cryptodires and 14 pleurodires) representing eight families indicated from three to eighteen components per species. ${ }^{129}$ Most species possess one or more proteins ranging from $59 \mathrm{kDa}$ to $65 \mathrm{kDa}$, but they vary in components $\leq 35 \mathrm{kDa}$. In the Asian four-eyed turtle (Sacalia bealei), the largest detectable component was a $41 \mathrm{kDa}$ glycoprotein. This comparative analysis demonstrates greater species variation in Rathke's gland proteins than has previously been reported.

Further study of Kemp's ridley sea turtle has revealed an enzyme with a mass of $\geq 200 \mathrm{kDa}$ that catalyzes the cleavage of the $\gamma$-glutamyl bond in a variety of donor substrates and the transfer of the $\gamma$-glutamyl group to water (hydrolysis) or to acceptor substrates possessing a free amino group. ${ }^{130}$ This enzyme may produce peptides in a fashion similar to that of the mammalian $\gamma$-glutamyl transpeptidases. Its significance in the secretions is unclear.

\subsection{Mental gland}

More than twenty genera in the Emydidae, Platysternidae, and Testudinidae possess paired epidermal invaginations called mental glands that are situated in the throat region. ${ }^{131}$ Mental glands range in complexity from shallow (possibly vestigial) invaginations devoid of glandular tissue to large, multilobed secretory sacs. These glands are enlarged in male tortoises (Gopherus spp.) and actively secrete during the mating season. ${ }^{132,133}$

Adult desert tortoises (Gopherus agassizii) identify familiar conspecifics on the basis of mental gland secretions. ${ }^{133}$ Male
Texas tortoises (Gopherus berlandieri) exhibit combat behavior, including head bobbing and shell ramming, in response to these exudates and to the $\mathrm{C}_{8}-\mathrm{C}_{18}$ FFAs they contain. ${ }^{134}$ TLC also has suggested that triacylglycerols, sterols, and phospholipids occur in the secretions of Gopherus spp. ${ }^{132}$

Gel electrophoresis of the glandular exudates of male and female desert, Texas, Bolson's (Gopherus flavomarginatus), and gopher (Gopherus polyphemus) tortoises has revealed species and sexual differences in protein composition. ${ }^{132}$ Males of the closely related desert and Bolson's tortoises displayed a band that was absent in the secretions of other males, and only male desert and Texas tortoises displayed bands denoting esterase activity. Females of all species displayed a band that was absent in males. An analysis by gel electrophoresis of male desert tortoises from Nevada, USA, revealed twelve to seventeen mental gland proteins ranging in mass from $25 \mathrm{kDa}$ to $115 \mathrm{kDa} .{ }^{133}$ Banding patterns among males were similar, but individual differences were observed in the number and size of high mass components.

\section{Crocodylia}

\subsection{Gular gland}

All modern crocodylians possess a paired evertible gland known as the gular gland that is located on the ventral aspect of the lower jaw in skin folds next to each mandibular ramus. ${ }^{135,136}$ Females are believed to scent mark nest sites with this gland by rubbing their lower jaw on the ground. ${ }^{137}$

The gular gland secretions of the American alligator (Alligator mississippiensis) contain 1, 6, $\mathrm{C}_{14}-\mathrm{C}_{18} \mathrm{FFAs}$, and 72. ${ }^{138}$ TLC analyses of the American alligator and other crocodylians have suggested the presence of additional compound classes, such as alcohols and triacylglycerols, in addition to demonstrating taxonomic, sexual, and individual variation in secretion composition. ${ }^{135,139,140}$

\subsection{Paracloacal gland}

The paracloacal gland is a paired organ embedded in the cloacal walls on each side of the vent of all modern crocodylians. ${ }^{136}$ This gland is thought to produce pheromones used in mating and/or nesting activities, but its specific function is unknown. ${ }^{137} \mathrm{We}$ observed a small group of free-ranging juvenile American alligators in Louisiana, USA, rapidly disperse when thawed paracloacal gland secretions from several adult males were poured into a water channel where they had aggregated to feed. ${ }^{141}$ Thus, perhaps, these secretions denote aggressive adults. TLC analyses of the secretions suggest the presence of hydrocarbons, FFAs, alcohols, triacylglycerols, sterols and their esters, and phospholipids, as well as species, sexual, and possible individual variation in secretion composition. ${ }^{139,140}$

$\beta$-Farnesene (126) and 1 occur in all genera of caimans, Caiman, ${ }^{136,142,143}$ Melanosuchus, ${ }^{136}$ and Paleosuchus. ${ }^{144}$ Squalene (1) comprises $>50 \%$ of the secretions of adult female American crocodiles (Crocodylus acutus), but $<4 \%$ of the secretions of juveniles or adult males. ${ }^{145}$ Pentadecane is a minor component of juvenile female American crocodiles. ${ }^{145}$

$\beta$-Springene (129), a diterpene homolog of $\mathbf{1 2 6}$, is abundant in the secretions of juvenile American alligators, but it is absent in adults. ${ }^{146-148}$ Similarly, the cyclic diterpene cembrene A (130) is 
<smiles>C=C(/C=C\C)CCC=C(C)C</smiles>

118<smiles>C/C=C(C)\C=C\CC(C)C</smiles>

119<smiles>C/C=C(C)\C=C\CC(C)C</smiles>

120<smiles>CC(C)=CCCC(C)CCO</smiles>

121<smiles>CC=C(C)C=CC[C@@H](C)CCCC(C)C</smiles>

122<smiles>C/C=C(C)\C=C\CC(C)CCC=C(C)C</smiles>

125<smiles>CC(C)=CCC/C(C)=C/CCC(C)CCO</smiles>

128<smiles>C=C(C)C(CC)C/C=C(\C)CC/C=C(\C)CCC=C(C)C</smiles>

130<smiles>C/C=C(C)\C=C\C[C@H](C)CCCC(C)C</smiles>

123<smiles>CC=C(C)C=CCC(C)CCC=C(C)C</smiles>

124<smiles>C=CC(=C)CCC=C(C)CCC=C(C)C</smiles>

126<smiles>CC(C)CCCC(C)CCCC(C)CC(=O)O</smiles>

127<smiles>C=CC(=C)CC/C=C(\C)CC/C=C(\C)CCC=C(C)C</smiles>

129<smiles>C=C(C)C(C/C=C(\C)CC/C=C\CC(=O)CC(C)C)CCC</smiles>

The direct analysis of secretion extracts in several studies has revealed the presence of $\mathrm{C}_{14}-\mathrm{C}_{18}$ FFAs in alligatorids (Alligator $^{148,150}$ and Paleosuchus ${ }^{155}$ ) and crocodylids (Crocodylus $^{145}$ and Osteolaemus ${ }^{152}$ ). On the other hand, an analysis of the American alligator in which FFAs were first converted to methyl esters showed the presence of twelve unbranched acids containing seven to eighteen carbons. ${ }^{146}$ Trace amounts of a sesquiterpene acid, 3,7,11-trimethyldodecanoic acid (127), also were observed.

The presence of alcohols in the secretions of adult American alligators was suggested by TLC analyses, ${ }^{139,140}$ but GC-MS studies have revealed only 1-dodecanol and 1-tetradecanol, each present in trace amounts, exclusively in juveniles. ${ }^{146}$ Likewise, a majority of the $\mathrm{C}_{13}-\mathrm{C}_{18}$ primary alcohols in the American crocodile were observed exclusively in hatchlings and juveniles. ${ }^{145}$ Adult Chinese alligators, on the other hand, possess an abundance of saturated and mono- and diunsaturated $\mathrm{C}_{12}-\mathrm{C}_{18}$ primary alcohols. ${ }^{150}$ 3-Dodecen-1-ol, 1-dodecanol, and an array of unsaturated $\mathrm{C}_{15}-\mathrm{C}_{18}$ alcohols are present in females, but absent in males. Citronellol (121) occurs in the genera Caiman ${ }^{142,143}$ and Paleosuchus, ${ }^{155}$ and 2,3-dihydrofarnesol (DHF, 128) occurs in trace amounts in the brown caiman (Caiman crocodilus fuscus). ${ }^{\mathbf{1 4 3}}$

Wax monoesters are the predominant constituents of the paracloacal glands of many crocodylians. American alligators possess various esters of primary alcohols including $\mathrm{C}_{10}-\mathrm{C}_{18}$ acetates, $\mathrm{C}_{10}-\mathrm{C}_{14}$ butanoates, $\mathrm{C}_{8}-\mathrm{C}_{18}$ 3-methylbutanoates, $\mathrm{C}_{12}-\mathrm{C}_{14}$ hexanoates, $\mathrm{C}_{12}$ and $\mathrm{C}_{14}$ octanoates, dodecyl decanoate, $\mathrm{C}_{10}-\mathrm{C}_{14}$ dodecanoates, $\mathrm{C}_{10}-\mathrm{C}_{16}$ tetradecanoates, tetradecyl hexadecanoate, and dodecyl octadecanoate. ${ }^{146,148}$ With the exception of farnesyl acetate, 3-methylbutanoate, and hexanoate, the alcohol moieties of these compounds are unbranched. Sexual differences have not been observed in the composition of the 
<smiles>[GeH2]=[Te]</smiles><smiles>O[As]</smiles><smiles>CCC(CCCC(CC)C(=O)CC(=O)O[C@H]1CC[C@@]2(C)C(CC[C@@H]3[C@@H]2CC[C@]2(C)[C@@H](C)CC[C@H]32)C1)CCc1ccccc1</smiles><smiles>CCC(CCCC(CC)C(O)CC)CCc1ccccc1</smiles><smiles>CCC(=O)O[C@H]1CC[C@@]2(C)C(=CC[C@@H]3[C@@H]2CC[C@]2(C)[C@@H](C)CC[C@H]32)C1</smiles><smiles>CCCC(O)C(CC)CCCC(CC)CCc1ccccc1</smiles>

136<smiles>CCCC(CC)CCCC(CC)CCc1ccccc1</smiles>

137<smiles>O[GeH2]</smiles><smiles>CCC(C)CCCC(CC)CC</smiles><smiles>C=C[C@H]1CC[C@H]2[C@H]3CC=C4C[C@@H](OC)CC[C@]4(C)[C@H]3CC[C@@]21C</smiles>

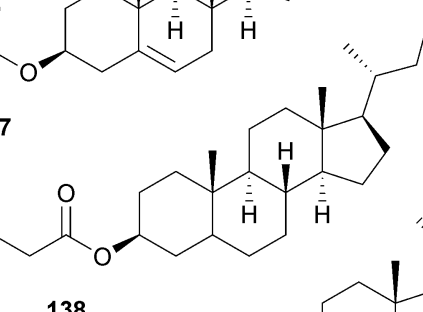<smiles>C1=CCCCCCCCCCC1</smiles> 

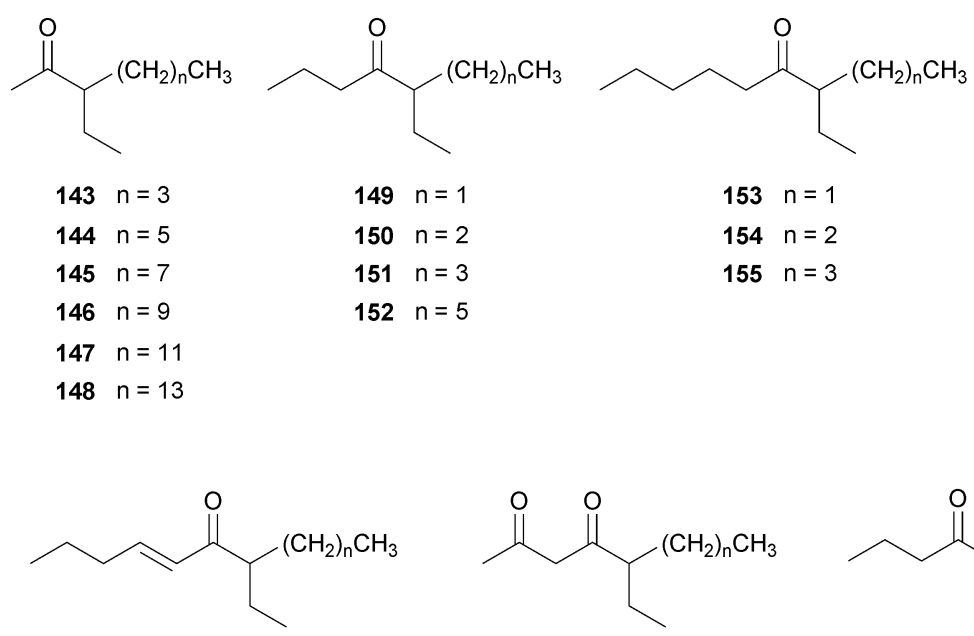

$\begin{array}{ll}167 & \mathrm{n}=1 \\ 168 & \mathrm{n}=2 \\ 169 & \mathrm{n}=3 \\ 170 & \mathrm{n}=4 \\ 171 & \mathrm{n}=5 \\ 172 & \mathrm{n}=7 \\ 173 & \mathrm{n}=9\end{array}$

$174 \mathrm{n}=1$

$175 n=3$

$176 \mathrm{n}=5$

$177 n=7$

$178 \mathrm{n}=9$

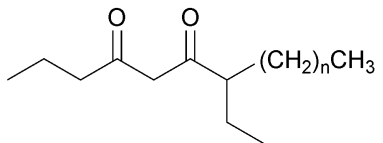

$179 \mathrm{n}=1$

$180 \mathrm{n}=3$

$181 \mathrm{n}=5$

$182 n=7$

$183 n=9$

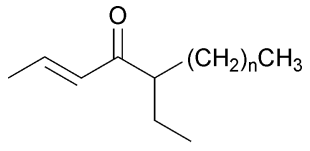

$160 \mathrm{n}=1$

$161 \mathrm{n}=2$

$162 n=3$

$163 n=4$

$164 \mathrm{n}=5$

$165 n=7$

$166 n=9$

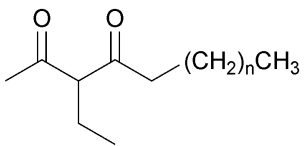

$184 \mathrm{n}=1$

$185 n=3$ in wax ester composition. ${ }^{150}$ The primary alcohol moieties of these compounds range in females from $\mathrm{C}_{7}-\mathrm{C}_{18}$ and in males from $\mathrm{C}_{12}-\mathrm{C}_{18}$. Hexadecenoates occur in females, but not in males. Females possess twenty-seven $\mathrm{C}_{12}-\mathrm{C}_{18}$ acetates, whereas males possess only three monounsaturated $\mathrm{C}_{15}, \mathrm{C}_{16}$, and $\mathrm{C}_{17}$ acetates. Alkanoates ranging from $\mathrm{C}_{12}-\mathrm{C}_{18}$ have been found in both sexes of the Chinese alligator, but the structural details of these compounds are unknown. The chain lengths and relative abundances of the alcohol moieties of esters in the secretions of some crocodylians correspond to those of the free alcohols present, suggesting that they are precursors or, more likely, degradation products of the esters.

The paracloacal glands of the American crocodile were found to contain $\mathrm{C}_{12}-\mathrm{C}_{20}$ acetates, $\mathrm{C}_{13}-\mathrm{C}_{18}$ butanoates, $\mathrm{C}_{15}-\mathrm{C}_{16}$ hexanoates, and $\mathrm{C}_{8}$ and $\mathrm{C}_{12}$ octadecenoates, in addition to $\mathrm{C}_{12}-\mathrm{C}_{20}$ formates, primarily $\mathrm{C}_{13}-\mathrm{C}_{18}$ compounds. ${ }^{144}$ Similar formates are known from the skin glands of some African antelopes (Bovidae, Mammalia). ${ }^{156}$ Citronellyl esters and a DHF ester were observed primarily in hatchling and juvenile American crocodiles. ${ }^{145}$ Brown caimans from Costa Rica were found to contain citronellyl acetate, butanoate, and hexanoate as well as twenty $\mathrm{C}_{2}-\mathrm{C}_{18}$ DHF esters. ${ }^{136,143}$ DHF hexanoate and DHF octanoate also occur in the yacare caiman (Caiman yacare). ${ }^{136}$

Adults of the African dwarf crocodile, on the other hand, contain the unusual ethyl-branched ketone $\mathbf{1 3 2}$ as the major volatile component of the paracloacal glands; it is absent in juveniles. ${ }^{152}$ Two enantiomers of 132 , the $(3 S, 7 S)$ - and the $(3 S, 7 R)$-isomers, were observed in proportions ranging from $>9$ : 1 to $<1: 9$, respectively. This extreme individual variation may have been introduced by including samples of different (unidentified) subspecies or secretion donors that ranged in age from 8 to 35 years.

A new family of aliphatic aldehydes, ketones, and $\beta$-diketones possessing an ethyl branch adjacent to the carbonyl group was reported from the paracloacal glands of the common caiman (Caiman crocodilus), the broad-snouted caiman (Caiman latirostris), the yacare caiman, the dwarf caiman, and the smooth-fronted caiman. ${ }^{157}$ Forty-three compounds were observed in the Caiman species and sixteen were observed in the Paleosuchus species. 3-Ethylnonan-4-one (144), 5-ethylundecan6-one (155), 2-ethyltetradecanal (159), 5-ethylnon-2-en-4-one (162), 3-ethylnon-5-en-4-one (167), 7-ethylundec-4-en-6-one (169), and 7-ethylundecane-4,6-dione (180) occur in all five species. Minor differences between males and females were noted for some compounds, but sexual variation could not be assessed because sample sizes were small and secretions were pooled from up to five adults. One unbranched ketone, heptan-3-one, was observed in a male broad-snouted caiman.

The ethyl-branched structures are not obviously related to those of other known compounds from the paracloacal glands of caimans or other crocodylians except 132. Krückert et al. ${ }^{157}$ postulated that these compounds are derived via fatty acid- or polyketide-derived biosynthesis in which the normal malonate extender unit is replaced by an ethyl malonate unit. Such products are typical of microorganisms. Krückert et al. observed several types of bacteria, including clostridia and propionibacteria, in the glandular secretions of a common caiman. However, they failed to isolate microbial strains producing the ethyl-branched compounds, leaving the biosynthetic origin of these compounds an open question.

\section{Discussion}

\subsection{From TLC to structural identifications}

TLC, despite its limitations compared to modern analytical methods, has revealed the complexity of lipid mixtures from the tetrapod integument and permitted tentative characterizations of 
secretion components. ${ }^{158}$ TLC analyses also have indicated possible sources of variation and adaptive patterns in skin chemical profiles. Comparisons of the epidermal lipids of squamates, birds, and mammals, for example, reveal uniformity in the polar compounds, presumably due to selection for stability among components that impede water loss. ${ }^{3,16,159}$ Nonpolar lipids may contribute to the transepidermal water barrier, ${ }^{2,14,15}$ but they appear to function foremost as semiochemicals. ${ }^{16}$ TLC analyses of nonpolar lipids from the reptilian integument demonstrate taxonomic, sexual, age-class, and other sources of variation consistent with the hypothesized multifunctionality of these compounds.

TLC studies also have demonstrated anatomical differences in skin chemistry. The contrasting profiles of lipids from the epidermis and the scent glands of snakes, for example, are believed to reflect the different functions of these tissues - the epidermis as an impediment to water loss, and the scent glands as a source of predator deterrents or other semiochemicals. ${ }^{18,19}$ Detailed structural studies are needed to further elucidate contrasts in epidermal and glandular products. Lipids on the epidermis are vulnerable to evaporative loss, thus the compounds that are produced or survive there may be less volatile than are those from other exocrine sources. Similarly, fatty acids in the outer portion of the skin typically exhibit greater saturation than do those from internal tissues, and thus they are less prone to oxidative damage from the environment. ${ }^{40}$ Whether compounds from the epidermis generally exhibit greater degrees of saturation than do comparable glandular products needs to be examined.

Behavioral studies suggest the existence of regional anatomical differences in the chemistry of the epidermis. For example, snake pheromones $^{8}$ and kairomones from ophiophagous snakes ${ }^{160}$ arise specifically from the dorsolateral skin. Detailed chemical comparisons of different regions of nonglandular epidermis may help to focus on the behavioral releasers in these and other organismal interactions.

\subsection{Chemical diversity revealed}

Identifications of lipids from the epidermis of squamates reveal a diverse chemistry based upon steroids, fatty acids, and their derivatives. Elucidations of compounds from tuatara, turtles, and crocodylians are needed for a more comprehensive picture of the skin surface chemistry of modern reptiles. Nonetheless, the presence of steroids, FFAs, triacylglycerols, and other lipid classes in amphibians attests to the antiquity of these compounds on the tetrapod epidermis. ${ }^{30,161,162}$ It is worth noting the occurrence in anurans of glucosylceramides, which are believed to play a role in the water barrier of mammals. ${ }^{161}$

The integument of vertebrates has long been recognized as a source of novel natural products featuring unusual carbonchain lengths, branching patterns, and unsaturation sites. ${ }^{1}$ The identifications of long-chain alcohols and methyl ketones from squamates, dianeackerone (132) and other ethyl-branched lipids from crocodylians, and numerous other compounds isolated from reptiles, are consistent with this view. The biological significance of these novel structures remains to be clarified. The long-chain, nonvolatile skin lipids of snakes may be related to selection for persistent scent trails. Prairie rattlesnakes (Crotalus viridis viridis) in Wyoming, USA, for example, are believed to orient to dens via trails lingering on the ground months after conspecifics have deposited them. ${ }^{163}$ Overall, the unusual chemistry of the reptilian integument likely confers specificity for chemical communication both within and between species. Interspecific interactions for which such specificity may be advantageous include those involving aposematic chemicals that signal predators and ectoparasites. The deterrence of ectoparasites by nonhost odors is an underappreciated aspect of vertebrate chemical defense that may involve the elaboration of unusual skin compounds. ${ }^{6}$

In some cases, distinctive chemical profiles may be achieved by subtle modifications of existing biosynthetic pathways. LeMaster and Mason, ${ }^{34}$ for example, postulated that the different mixtures of methyl ketone sex attractants of garter snakes from different dens reflect microevolutionary shifts in the enzymes responsible for their biosynthesis. Aside from enzymatic activities, macromolecules in skin secretions may themselves act as pheromones, provide a matrix for the slow release of volatile semiochemicals, or serve other functions. ${ }^{164}$

The secretion of dietary compounds, sometimes with structural modification, may contribute to the chemical diversity of the vertebrate integument. New Guinean birds, specifically pitohuis (Pitohui spp.) and the blue-capped ifrita (Ifrita kowaldi), are prime subjects of a growing case for the defensive sequestration of ingested chemicals. ${ }^{165}$ The feathers and other tissues of these birds contain batrachotoxins, a family of steroidal alkaloids that bind $\mathrm{Na}^{+}$channels and depolarize electrogenic membranes, thus potentially deterring predators and ectoparasites. These toxins may be acquired from the melyrid beetles (Choresine spp.) that these birds consume. ${ }^{166}$ Similarly, as described above, Asian water snakes (Rhabdophis spp.) appear to sequester cardiotonic bufadienolides from a type of vertebrate prey, toads.

The epidermal and glandular secretions of several squamates have been shown to contain $\mathbf{2 7 , 4 2}$, and other sterols that typically are produced by plants and microorganisms. These compounds may originate in the diet or perhaps are produced by enteric bacteria. Their significance on the skin is unclear. It has been postulated that they are eliminated via the integument to prevent their excessive accumulation. ${ }^{55}$

\subsection{Biosynthesis by associated microorganisms?}

Microorganisms residing on the mammalian integument are known to contribute to the skin chemistry of their hosts. ${ }^{167}$ The microbial lipolysis of triacylglycerols on the epidermis of humans, for example, is the main source of FFAs on the skin surface. ${ }^{168}$ Bacteria occupying the reducing environments of mammalian skin glands also generate volatile compounds, including some used as semiochemicals. ${ }^{167}$ Microorganisms contributing to the characteristic skin chemical profiles of their hosts typically exist in stable communities.

Several studies have attempted to characterize the resident microbiota of reptilian skin glands in light of the possible microbial contribution to glandular chemistry. ${ }^{79,125,169}$ A study of the western diamondback rattlesnake, for example, compared bacteria in the scent glands and the cloacal fluids in order to identify scent gland residents potentially responsible for generating secretion volatiles. ${ }^{79}$ Typical enteric bacteria were 
isolated from both scent glands and cloacal fluids. A few bacterial species were observed only in the scent glands, but the number of isolates was small, suggesting a low survivorship in the culture media or the occurrence of transient organisms.

Bacteria in the gular and paracloacal glands of free-ranging American alligators from Louisiana, USA, were identified to evaluate whether the different lipid profiles of these organs could be related to different populations of microorganisms. ${ }^{169}$ Twenty-three bacterial species were identified from both glands. Most species, however, were represented by only one isolate from either gland and many appeared to be transient enteric or waterborne organisms. Thus, as in the investigation on the origin of ethyl-branched compounds in caimans, ${ }^{157}$ questions on the existence in crocodylian skin glands of a resident microbiota and on the microbial contribution to glandular exudates remain unanswered.

\section{Prospectus}

The integument is uniquely situated at the interface of the organism and the environment, providing a first line of defense against external insults and selectively imparting synthesized or acquired chemicals to the surroundings. Some authors have focused on water conservation achieved through the transepidermal barrier as the prevailing factor in shaping the chemistry of the reptilian epidermis. ${ }^{31,163}$ We point to the unrelenting and pervasive imperatives of defense against microorganisms, ectoparasites, and predators, and of pheromonal communication, as additional concurrent adaptations to terrestrial life. Demonstrations of the functions of chemicals from the integument are needed to advance more explicit evolutionary hypotheses.

We have focused on natural products from selected exocrine organs of the reptilian integument and described their known or suspected activities. The themes investigated in the studies recounted here, such as the effects of environmental variables on skin lipid composition, the microevolution of pheromones, and the dietary sequestration of skin chemicals, should prompt future studies and may clarify related topics. Quay, ${ }^{170}$ for example, regarded the integumental glands of reptiles as histogenetically related but nonhomologous organs. Can elucidations of glandular products or genes governing their production shed light on the evolutionary affinities of these structures? Organosulfur, heterocyclic, and macrocyclic compounds, which frequently occur in the secretions of mammalian skin glands, ${ }^{167}$ are seldom, if ever, reported from reptiles. Does the apparent paucity of these or other compounds in the skin of reptiles reflect constraints on their biosynthetic capabilities? What can studies of reptiles and other tetrapods reveal about the skin chemistry of early amniotes? Structural elucidations coupled with molecular methodologies and a broad zoological scope may provide the answers to these and other questions on the biosynthesis, function, and evolution of natural products from the tetrapod integument.

\section{Acknowledgements}

U. R. Bernier, J. W. Daly, W. Fenical, H. M. Fales, H. W. Greene, M. Kramer, T. L. Leto, R. W. McDiarmid, F. M. Schell, and P. W. Wertz commented on the manuscript. R. Greene,
P. Lasker, D. T. Steere (Smithsonian Libraries, Washington, D.C.), M. Esman, R. Mazur, W. Olson, and E. Tyler (National Agricultural Library, Beltsville, Maryland) provided references. Y. Itagaki translated some references. This paper is dedicated to Professor Paul F. A. Maderson for his seminal contributions on the structure, development, and evolution of the vertebrate integument.

\section{References}

1 N. Nicolaides, Science, 1974, 186, 19.

2 N. F. Hadley, The Adaptive Role of Lipids in Biological Systems, Wiley, New York, 1985.

3 D. T. Downing, M. E. Stewart, P. W. Wertz, S. A. Colton, VI and J. S. Strauss, Comp. Biochem. Physiol., B, 1983, 76, 673.

4 H. B. Lillywhite, J. Exp. Biol., 2006, 209, 202.

5 M. D. Shawley, S. R. Pillai and G. E. Hill, J. Avian Biol., 2003, 34, 345.

6 P. J. Weldon and J. F. Carroll, in Insect Repellents: Principles, Methods, and Uses, ed. M. Debboun, S. P. Frances, and D. Strickman, CRC, Boca Raton, Florida, 2007, p. 47.

7 H. W. Greene, in Biology of the Reptilia, Vol. 16, Ecology B: Defense and Life History, ed. C. Gans and R. B. Huey, Alan R. Liss, New York, 1988, p. 1

8 R. T. Mason, in Biology of the Reptilia, Vol. 18, Physiology E: Hormones, Brain, and Behavior, ed. C. Gans and D. Crews, University of Chicago Press, Chicago, 1992, p. 114.

9 M. Gabe and H. Saint Girons, Mem. Mus. Natl. Hist. Nat., Ser. A (Paris), 1965, 33, 149.

10 A. M. Whiting, Ph.D. Thesis, Pennsylvania State University, 1969.

11 V. E. Sokolov, E. L. Komova and O. F. Chernova, Cutaneous Glands of Reptiles (Reptilia): Review of Research, A.N. Severtsov Institute of Evolutionary Morphology and Ecology of Animals, U.S.S.R. Academy of Science, Moscow, 1994.

12 D. G. Ahern and D. T. Downing, Lipids, 1974, 9, 8.

13 P. J. Weldon and D. Bagnall, Comp. Biochem. Physiol., B, 1987, 87, 345.

14 J. B. Roberts, Ph.D. Thesis, University of Kansas, 1980.

15 J. B. Roberts and H. B. Lillywhite, Science, 1980, 207, 1077.

16 R. R. Burken, P. W. Wertz and D. T. Downing, Comp. Biochem. Physiol., B, 1985, 81, 315.

17 F. M. Schell and P. J. Weldon, Agric. Biol. Chem., 1985, 49, 3597.

18 P. J. Tolson, Occas. Pap. Mus. Zool., Univ. Michigan, 1987, 715, 1.

19 P. J. Weldon, H. W. Sampson, L. Wong and H. A. Lloyd, J. Herpetol., 1991, 25, 367.

20 M. C. Devine, Ph.D. Thesis, University of Michigan, 1977.

21 C. S. Birkby, P. W. Wertz and D. T. Downing, Comp. Biochem. Physiol., B, 1982, 73, 239.

22 R. T. Mason, J. W. Chinn and D. Crews, Comp. Biochem. Physiol., $B, 1987,87,999$.

23 R. T. Mason, H. M. Fales, T. H. Jones, L. K. Pannell, J. W. Chinn and D. Crews, Science, 1989, 245, 290.

24 J. Jacob, B. Ziemsen and U. Hoppe, Z. Naturforsch., C, 1993, 48, 80.

25 R. T. Mason and W. H. N. Gutzke, J. Chem. Ecol., 1990, 16, 27.

26 R. T. Mason, Brain Behav. Evol., 1993, 41, 261.

27 J. T. Bortz, P. W. Wertz and D. T. Downing, J. Invest. Dermatol, 1989, 93, 723.

28 J. C. Ball, J. Herpetol., 2000, 34, 266.

29 J. C. Ball, J. Herpetol., 2004, 38, 124.

30 T. Tsumita, T. Niwa, Y. Shimoyama and H. Tomita, Snake, 1979, 11, 19.

31 R. T. Mason, T. H. Jones, H. M. Fales, L. K. Pannell and D. Crews, J. Chem. Ecol., 1990, 16, 2353.

32 M. P. LeMaster and R. T. Mason, Chemoecology, 2001, 11, 149.

33 M. P. LeMaster and R. T. Mason, J. Chem. Ecol., 2002, 28, 1269.

34 M. P. LeMaster and R. T. Mason, J. Chem. Ecol., 2003, 29, 1027.

35 Y. Murata, H. J. C. Yeh, L. K. Pannell, T. H. Jones, H. M. Fales and R. T. Mason, J. Nat. Prod., 1991, 54, 233.

36 D. Bagnall, N. Stolowich and P. J. Weldon, unpublished work.

37 R. T. Mason in Problem Snake Management: The Habu and the Brown Treesnake, ed. G. H. Rodda, Y. Sawai, D. Chiszar and H. Tanaka, Comstock, Ithaca, New York, 1999, p. 196. 
38 P. W. Wertz and D. T. Downing, Science, 1982, 217, 1261; L. Wenmei, R. Sandhoff, M. Kono, P. Zerfas, V. Hoffman, B. C.-H. Ding, R. L. Proia and C.-X. Deng, Int. J. Biol. Sci., 2007, 3, 120 .

39 W. Abraham, P. W. Wertz, R. R. Burken and D. T. Downing, J. Lipid Res., 1987, 28, 446

40 P. W. Wertz, P. M. Stover, W. Abraham and D. T. Downing, J. Lipid Res., 1986, 27, 427.

41 A. Bolliger and D. Varga, Aust. J. Exp. Biol., 1960, 38, 265.

42 A. Bolliger and D. Varga, Nature, 1961, 190, 1125; M. T. R. Subbiah, Lipids, 1973, 8, 158; J. Jacob and D. E. Pomeroy, Comp. Biochem. Physiol., B, 1979, 64, 301.

43 M. M. Antoniazzi, C. Jared and L. C. U. Junqueira, J. Morphol., 2005, 221, 101

44 W. E. Cooper, P. López and A. Salvador, Anim. Behav., 1994, 47, 1401.

45 P. Lopez, A. Salvador and W. E. Cooper, Jr., J. Comp. Psychol., 1994, 111, 105.

46 P. López and J. Martin, J. Chem. Ecol., 2005, 31, 2913.

47 A. C. Alberts, Brain Behav. Evol., 1993, 41, 255.

48 N. B. Chauhan, J. Anim. Morphol. Physiol., 1986, 33, 73.

49 N. B. Chauhan, J. Anim. Morphol. Physiol., 1986, 33, 63.

50 N. B. Chauhan, J. Anim. Morphol. Physiol., 1987, 34, 89.

51 N. B. Chauhan, J. Anim. Morphol. Physiol., 1987, 34, 99.

52 P. J. Weldon, B. S. Dunn, Jr., C. A. McDaniel and D. I. Werner, Comp. Biochem, Physiol., B, 1990, 95, 541.

53 A. C. Alberts, T. R. Sharp, D. I. Werner and P. J. Weldon, J. Chem. Ecol., 1992, 18, 703.

54 P. López and J. Martin, Z. Naturforsch. C, 2005, 60, 632.

55 P. López, L. Amo and J. Martin, J. Chem. Ecol., 2006, 32, 473

56 J. Martin and P. López, Funct. Ecol., 2006, 20, 1087.

57 J. Martin and P. López, Proc. R. Soc. London, Ser. B, 2006, 273, 2619.

58 J. Martin and P. López, Biol. Lett., 2007, 3, 125

59 J. Martin and P. López, Biochem. Syst. Ecol., 2006, 34, 691.

60 P. López and J. Martin, Z. Naturforsch., C, 2006, 61, 763.

61 J. Martin and P. López, Chemoecology, 2006, 16, 31.

62 P. López and J. Martin, Biol. Lett., 2005, 1, 404.

63 P. López and J. Martin, Z. Naturforsch., C, 2005, 60, 915.

64 A. C. Alberts, Am. Nat., 1992, 139, S62.

65 C. A. Escobar, A. Labra and H. M. Niemeyer, J. Chem. Ecol., 2001, 27, 1677.

66 C. M. Escobar, C. A. Escobar, A. Labra and H. M. Niemeyer, J. Chem. Ecol., 2003, 29, 629.

67 S. Louw, B. V. Burger, M. Le Roux and J. H. Van Wyk, J. Chem. Ecol., 2007, 33, 1806.

68 A. C. Alberts, J. Chem. Ecol., 1990, 16, 13.

69 A. C. Alberts, Copeia, 1991, 1991, 69.

70 A. C. Alberts, J. A. Phillips and D. I. Werner, Copeia, 1993, 1993, 775 .

71 A. C. Alberts and D. I. Werner, Anim. Behav., 1993, 46, 197.

72 S. E. Trauth, W. E. Cooper, Jr., L. J. Vitt and S. A. Perrill, Herpetologica, 1987, 43, 458; W. E. Cooper, Jr. and S. E. Trauth, Herpetologica, 1992, 48, 229.

73 W. E. Cooper, Jr, W. R. Garstka and L. J. Vitt, Herpetologica, 1986, 42, 361 .

74 W. E. Cooper, Jr. and W. R. Garstka, J. Exp. Zool., 1987, 242, 249.

75 H. I. Rosenberg and A. P. Russell, Can. J. Zool., 1980, 58, 865.

76 K. C. Richardson and P. M. Hinchliffe, Copeia, 1983, 1983, 161.

77 H. I. Rosenberg, A. P. Russell and M. Kapoor, Copeia, 1984, 1984, 1025.

78 B. A. Young, C. Marsit and K. Meltzer, Anat. Rec., 1999, 256, 127

79 P. J. Weldon, R. Ortiz and T. R. Sharp, in Biology of the Pitvipers, ed. J. A. Campbell and E. D. Brodie, Jr., Selva, Tyler, Texas, 1992, p. 309.

80 F. R. Gehlbach, J. F. Wakins, II and H. W. Reno, Bioscience, 1968, 18, 784.

81 J. F. Watkins, II, F. R. Gehlbach and J. C. Kroll, Ecology, 1969, 50, 1098.

82 P. J. Weldon and L. McNease, Herpetologica, 1991, 47, 403.

83 A. H. Price and J. L. LaPointe, Copeia, 1981, 1981, 138.

84 J. Wright and P. J. Weldon, J. Chem. Ecol., 1990, 16, 2947.

85 P. J. Weldon and D. B. Fagre, J. Chem. Ecol., 1989, 15, 1589

86 K. J. Kissner, G. Blouin-Demers and P. J. Weatherhead, J. Herpetol., 2000, 34, 491.
87 M. J. Greene and R. T. Mason, Anim. Behav., 2003, 65, 905; M. J. Greene and R. T. Mason, in Chemical Signals in Vertebrates 10, ed. R. T. Mason, M. P. LeMaster and D. Müller-Schwarze, Springer, New York, 2005, p. 49.

88 B. M. Graves and D. Duvall, Southwest. Nat., 1988, 33, 339.

89 P. D. Oldak, Copeia, 1976, 1976, 320

90 B. A. Young, B. A. Frazer, B. Fried, M. Lee, J. Lalor and J. Sherma, J. Planar Chromatogr., 1999, 12, 196.

91 J. T. Simpson, T. R. Sharp, W. F. Wood and P. J. Weldon, Z. Naturforsch., C, 1993, 48, 953.

92 J. T. Simpson, P. J. Weldon and T. R. Sharp, Z. Naturforsch., C, 1988, 43, 914.

93 M. S. Blum, J. B. Byrd, J. R. Travis, J. F. Watkins, II and F. R. Gehlbach, Comp. Biochem. Physiol., 1971, 38B, 103.

94 R. R. Razakov and A. S. Sadyov, Khim. Prir. Soedin., 1986, 4, 421.

95 P. J. Weldon, H. A. Lloyd and M. S. Blum, Experientia, 1990, 46, 774.

96 W. F. Wood, J. M. Parker and P. J. Weldon, J. Chem. Ecol., 1995, 21, 213 .

97 P. J. Weldon and T. L. Leto, J. Herpetol., 1995, 29, 474

98 P. D. Oldak and W. B. Hebard, Georgetown Med. Bull., 1966, 20, 103.

99 K. Nakamura, Mem. Coll. Sci., Kyoto Imperial Univ., 1935, 10, 229.

100 M. A. Smith, Proc. Zool. Soc. London, 1938, 108, 575.

101 H. Fukada, Bull. Kyoto Gakugei Univ., Ser B, 1958, 12, 3.

102 H. Fukada, Bull. Kyoto Gakugei Univ., Ser B, 1961, 18, 13.

103 H. Asahi, Y. Kohtari, K. Chiba and A. Mishima, Fol. Opthalmol. Jpn., 1985, 36, 379.

104 H. Azuma, S. Sekizaki, T. Akizawa, T. Yasuhara and T. Nakajima, J. Pharm. Pharmacol., 1986, 38, 388.

105 T. Akizawa, T. Yasuhara, R. Jano and T. Nakajima, Biomed. Res., $1985,6,437$

106 T. Akizawa, J. Soc. Ochanomizu Med., 1986, 34, 85.

107 D. A. Hutchinson, A. Mori, A. H. Savitsky, G. M. Burghardt, X. Wu, J. Meinwald and F. C. Schroeder, Proc. Natl. Acad. Sci. U. S. A., 2007, 104, 2265.

108 A. Mori and G. M. Burghardt, J. Comp. Psych., 2000, 114, 408.

109 J. A. Blair and J. Graham, Biochem. J., 1954, 56, 286; J. A. Blair, Nature, 1957, 180, 1371; G. G. Villela and M. Thein, Experientia, 1967, 23, 722 .

110 W. A. Dunson, M. K. Dunson and A. D. Keith, J. Exp. Zool., 1978, 203, 461 .

111 C. C. de Haan, C. R. Biol., 2003, 326, 275; C. C. de Haan and A. Cluchier, in Herpetologia Bonnensis II. Proc. 13th Cong. Soc. Eur. Herpetol., ed. M. Vences, J. Köhler, T. Ziegler and W. Böhme, 2006, p. 211.

112 C. Gans, J. C. Gillingham and D. L. Clark, J. Herpetol., 1984, 18, 194.

113 B. Flachsbarth, M. Fritzsche, S. Schulz and P. J. Weldon, unpublished work.

114 Y. Hathout, C. Fenselau and P. J. Weldon, unpublished work.

115 G. N. Waagen, M.Sc. Thesis, University of Utah, 1972.

116 J. G. Ehrenfeld and D. W. Ehrenfeld, Copeia, 1973, 1973, 305.

117 P. J. Weldon and E. S. Gaffney, Naturwissenschaften, 1998, 85, 556.

118 D. C. Rostal, J. A. Williams and P. J. Weldon, Copeia, 1991, 1991, 1129.

119 G. M. Patton, M. A. Messinger and J. L. Carr, Proc. Louisiana Acad. Sci., 2004, 65, 22.

120 K. Kool, Aust. J. Herp., 1981, 1, 45

121 J. H. Brann and D. A. Fadool, J. Exp. Biol., 2006, 209, 1914.

122 P. J. Weldon and M. J. Tanner, Copeia, 1990, 1990, 575.

123 T. Eisner, T. H. Jones, J. Meinwald and J. M. Legler, Copeia, 1978, 1978, 714.

124 T. Eisner, W. E. Conner, K. Hicks, K. R. Dodge, H. I. Rosenberg, T. H. Jones, M. Cohen and J. Meinwald, Science, 1977, 196, 1347

125 P. J. Weldon, R. T. Mason, M. J. Tanner and T. Eisner, Comp. Biochem. Physiol., B, 1990, 96, 705.

126 W. E. Seifert, Jr., S. W. Gotte, T. L. Leto and P. J. Weldon, Comp. Biochem. Physiol., B, 1994, 109, 459.

127 G. Radhakrishna, C. C. Q. Chin, F. Wold and P. J. Weldon, Comp. Biochem. Physiol., B, 1989, 94, 375.

128 C. C. Q. Chin, R. G. Krishna, P. J. Weldon and F. Wold, Anal. Biochem., 1996, 233, 18

129 W. E. Seifert, W. McCord and P. J. Weldon, unpublished work. 
130 R. G. Krishna, C. C. Q. Chin, P. J. Weldon and F. Wold, Comp. Biochem. Physiol., B, 1995, 111, 257.

131 R. M. Winokur and L. M. Legler, J. Morphol., 1975, 147, 275.

132 F. L. Rose, R. Drotman and W. G. Weaver, Comp. Biochem. Physiol., 1969, 29, 847.

133 A. C. Alberts, D. C. Rostal and V. A. Lance, Herpetol. Monogr., 1994, 8, 116.

134 F. L. Rose, Comp. Biochem. Physiol., 1970, 32, 577.

135 P. J. Weldon and H. W. Sampson, Copeia, 1988, 1988, 80.

136 P. J. Weldon and J. W. Wheeler, in Crocodilian Biology and Evolution, ed. G. C. Grigg, F. Seebacher and C. E. Franklin, Surrey Beatty \& Sons, Chipping Norton, 2000, p. 286.

137 P. J. Weldon and M. W. J. Ferguson, Brain Behav. Evol., 1993, 41, 239.

138 P. J. Weldon, A. Shafagati and J. W. Wheeler, Z. Naturforsch., C, 1988, 42, 1345

139 P. J. Weldon, T. P. Scott and M. J. Tanner, J. Chem. Ecol., 1990, 16, 3 .

140 P. J. Weldon and M. J. Tanner, Biochem. Syst. Ecol., 1991, 19, 133.

141 P. J. Weldon, unpublished observation.

142 C. A. McDaniel, B. S. Dunn, Jr. and P. J. Weldon, Z. Naturforsch., C, 1998, 53, 932

143 J. W. Wheeler, S. A. Ibrahim and P. J. Weldon, Biochem. Syst. Ecol,, 1999, 27, 27.

144 J. W. Avery, A. Shafagati, A. Turner, J. W. Wheeler and P. J. Weldon, Biochem. Syst. Ecol., 1993, 21, 533.

145 S. García-Rubio, A. B. Attygalle, P. J. Weldon and J. Meinwald, J. Chem. Ecol., 2002, 28, 769 .

146 S. A. Ibrahim, J. W. Avery, P. J. Weldon and J. W. Wheeler, Z. Naturforsch., C, 1998, 53, 201.

147 S. Schulz, K. Krückert and P. J. Weldon, J. Nat. Prod., 2003, 66, 34.

148 P. J. Weldon, A. Shafagati and J. W. Wheeler, Lipids, 1988, 23, 727.

149 D. L. Mattern, W. D. Scott, C. A. McDaniel, P. J. Weldon and D. E. Graves, J. Nat. Prod., 1997, 60, 828.

150 B. S. Dunn, Jr., P. J. Weldon, R. W. Howard and C. A. McDaniel, Lipids, 1993, 28, 75.

151 G. A. Fester and F. A. Bertuzzi, Ber. Dtsch. Chem. Ges. B, 1934, 67, 365; G. A. Fester and F. A. Bertuzzi, An. Soc. Cient. Argent., 1934, 118, 222.

152 A. Whyte, Z.-C. Yang, K. Tiyanont, P. J. Weldon, T. Eisner and J. Meinwald, Proc. Natl. Acad. Sci. U. S. A., 1999, 96, 12246.

153 G. A. Fester, F. A. Bertuzzi and D. Pucci, Ber. Dtsch. Chem. Ges. B, 1937, 70, 37.
154 Z.-C. Yang, A. Whyte, A. B. Attygalle, P. J. Weldon, T. Eisner and J. Meinwald, Proc. Natl. Acad. Sci. U. S. A., 1999, 96, 12251.

155 A. Shafagati, P. J. Weldon and J. W. Wheeler, Biochem. Syst. Ecol., 1989, 17, 431

156 B. V. Burger, F.-C. Thien, M. Le Roux and W.-P. Mo, Z. Naturfosch., C, 1981, 36, 344; B. V. Burger, J. Greyling and H. S. C. Spies, J. Chem. Ecol., 1999, 25, 2099.

157 K. Krückert, B. Flachsbarth, S. Schulz, U. Hentschel and P. J. Weldon, J. Nat. Prod., 2006, 69, 863.

158 P. J. Weldon, in Practical Thin-layer Chromatography: A Multidisiplinary Approach, ed. B. Fried and J. Sherma, CRC Press, Boca Raton, Florida, 1996, p. 105.

159 Sterol glycosides and acylglucosylceramides are thought to contribute to the water barrier of reptiles and mammals, respectively - see ref. 38-40.

160 C. M. Bogert, Ann. N. Y. Acad. Sci., 1941, 41, 329.

161 P. C. Withers, S. S. Hillman and R. C. Drewes, J. Exp. Zool., 1984, 232, 11.

162 J. W. Daly, I. Karle, C. W. Meyers, T. Tokuyama, J. A. Waters and B. Witkop, Proc. Natl. Acad. Sci. U. S. A., 1971, 68, 1870; D. F. Johnson and J. W. Daly, Biochem. Pharmacol., 1971, 20, 2555; G. Habermehl and B. G. Christ, Naturwissenschaften, 1977, 64, 488.

163 B. M. Graves, D. Duvall, M. B. King, S. L. Lindstedt, and W. A. Gern, in Chemical Signals in Vertebrates 4, ed. D. Duvall, D. Müller-Schwarze and R. M. Silverstein, Plenum, New York, 1985 , p. 285

164 D. H. L. Robertson, S. Cheetham, S. Armstrong, J. L. Hurst, and R. J. Beynon, in Chemical Signals in Vertebrates 10, ed. R. T. Mason, M. P. LeMaster and D. Müller-Schwarze, Springer, New York, 2005, p. 183.

165 J. P. Dumbacher, B. M. Beehler, T. F. Spande, H. M. Garraffo and J. W. Daly, Science, 1992, 258, 799; J. P. Dumbacher, T. F. Spande and J. W. Daly, Proc. Natl. Acad. Sci. U. S. A., 2000, 97, 12970.

166 J. P. Dumbacher, A. Wako, S. R. Derrickson, A. Samuelson, T. F. Spande and J. W. Daly, Proc. Natl. Acad. Sci. U. S. A., 2004, 101, 15857

167 E. S. Albone, Mammalian Semiochemistry: The Investigation of Chemical Signals between Mammals, Wiley, 1984, New York.

168 D. Downing, J. Invest. Dermatol., 1970, 54, 395; A. R. Shalita, J. Invest. Dermatol., 1974, 62, 332; S. M. Puhvel, R. M. Reisner and M. Sakamoto, J. Invest. Dermatol., 1975, 64, 406.

169 P. A. Williams, W. Mitchell, G. R. Wilson and P. J. Weldon, Lett. Appl. Microbiol., 1990, 10, 73.

170 W. B. Quay, Am. Zool., 1972, 12, 95. 